Bulletin of Pharmaceutical Sciences
Assiut University

\title{
MACRO- AND MICROMORPHOLOGY OF THE LEAF, STEM, STEM BARK AND FRUIT OF CHORISIA SPECIOSA A. ST. HIL CULTIVATED IN EGYPT
}

\author{
M. A. Ramadan, F. M. Darwish, M. H. Assaf and E. M. Nasr ${ }^{*}$ \\ Department of Pharmacognosy, Faculty of Pharmacy, Assiut University, Assiut, Egypt
}

\begin{abstract}
Chorisia speciosa A. St. Hil. belongs to family Bombacaeae. There is no detailed information could be traced concerning the macro- and micromorphology of the leaves, stem and fruits of the plant, so this study is performed with the aim of finding their characters by which they could be identified and differentiated, in both the entire and powdered forms.
\end{abstract}

\section{INTRODUCTION}

Chorisia speciosa A. St. Hil is a member of the family Bombacaceae (Bombax, Baobab or Kapok family), which is a plant family of flowering plants, contains about 28 genera and about 200 species $^{1}$.

Plants of this family are perennial, deciduous and woody trees. They occur throughout the tropical and subtropical regions of the world especially in tropical America ${ }^{2}$.

In Egypt, Bombacaeae is represented by two genera, Bombax and Chorisia which are cultivated mostly for ornamental and shade purposes due to their large branches and brightly colored flowers ${ }^{3}$.

Chorisia is the name of a genus of about 20 species of large trees found in tropical and subtropical areas, including Mexico, Central America, South America, the Bahamas, the Caribbean, West Africa, and Southeast Asia. It was named in honor of the botanical artist and traveler Ludwig L. Choris (1795 - 1828, 19th century $)^{4}$.

Chorisia is mainly cultivated for its ornamental brilliant flowers since it blooms during autumn, adding a touch of color at the time when most blooms are fading. It is also cultivated for the silky fiber (or floss) that is obtained from the ripened seeds, so named as "silk floss tree". Additionally, because of its

Received in 16/11/2015 \& Accepted in 2/6/2016

*Corresponding author: E. M. Nasr, E-mail: erenymohsen5888@yahoo.com twisted shape, it is sometimes nicknamed as "the drunken tree"(4\&5).

These plants are traditionally used for many health disorders, e.g., headache, fever, diabetes, diarrhea, parasitic infections, peptic ulcer and rheumatism ${ }^{6}$.

Biologically, it was reported that some Chorisia species possess wide range of useful anti-inflammatory, hepatoprotective, cytotoxic, antioxidant and hypoglycemic with high safety $\operatorname{margins}^{(7-10)}$.

Chorisia is characterized by a bottleshaped trunk generally bulging in its lower third, measuring up to two meters in girth with thick conical sharp spines as an adaptation for dry times to store water. In young trees, the trunk is green due to its high chlorophyll content which makes it capable of performing photosynthesis when leaves are absent and with age, it turns to grey. Flowers usually appear when the tree is leafless ${ }^{11}$.

The silk floss tree (Ceiba speciosa A. St.Hil., formerly Chorisia speciosa A. St. Hil.), is a species of deciduous tree native to southern Brazil, Argentina, Bolivia, Paraguay, Peru and Ecuador, but it is also cultivated in many tropical areas and grows well in parts of southern California ${ }^{(4 \& 5)}$.

\section{Habitat}

Chorisia speciosa A. St. Hil trees (Fig. 1) are about $10-20 \mathrm{~m}$ height with a bottle-shaped 
spiny trunk. The leaves are deciduous, alternate and palmately compound with long petioles. The flowers are bisexual, solitary, pink, rose or violet in colour at the outer half of the petal while the inner part is creamy white or yellow with dark streaks that radiate from the center. The fruits are pear- shaped capsule with five woody valves, containing bean- sized brownish black seeds surrounded by a mass of cottonlike fibrous fluffy matter ${ }^{(11 \& 12)}$.

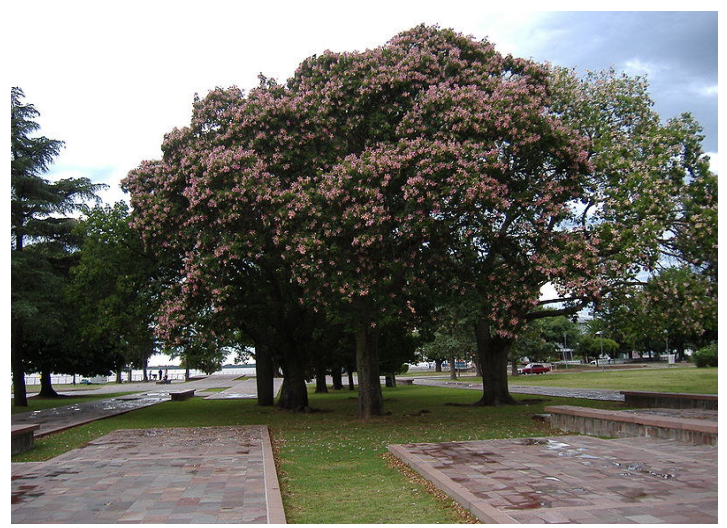

Fig. 1: Photo of the plant $\quad \mathrm{x} 0.01$

\section{MATERIAL}

Fresh samples of $C$. speciosa A. St. Hil. leaves, stem and fruits were collected during the flowering stage in the period of February to April, from the station of Ornamental plants, Faculty of Pharmacy, Assiut University and kindly identified and authenticated by late Prof. Dr. Naeem E. Keltawy, Professor of Ornamental Horticulture and Floriculture, Faculty of Agriculture, Assiut University. Different organ samples were preserved in a mixture of $70 \%$ alcohol - glycerin-water (1:1:1 $\mathrm{v} / \mathrm{v})$ and stored in a tightly closed container, other samples were separately air-dried and reduced to fine powder.

\section{THE LEAF}

\section{A- Macromorphology (Fig. 2)}

The leaves are deciduous, stipulate arranged alternately on the stem, palmately compound, with 5-7 leaflets radiating from a common point at the tip of the petiole and arranged like the 5 fingers of the hand. The petiole is $7-10 \mathrm{~cm}$ in length and $0.1-0.2 \mathrm{~cm}$ in diameter, cylindrical, more prominent on the lower surface (The midrib is prominent dorsally) and has a groove on the upper surface. Each leaflet is elliptically, oblong to obovate with symmetric base measuring $2-8 \mathrm{~cm}$ length and 1-3 cm width with a short petioleole of $0.1 \mathrm{~cm}$ in diameter and about $1.5 \mathrm{~cm}$ in length. It has an acuminate apex, serrate margin and showing reticulate pinnate vennation. The leaflets have smooth surfaces and thin papery texture. They have green upper (ventral) surfaces and paler lower (dorsal) ones. They are odourless and have a mucilagenous taste.

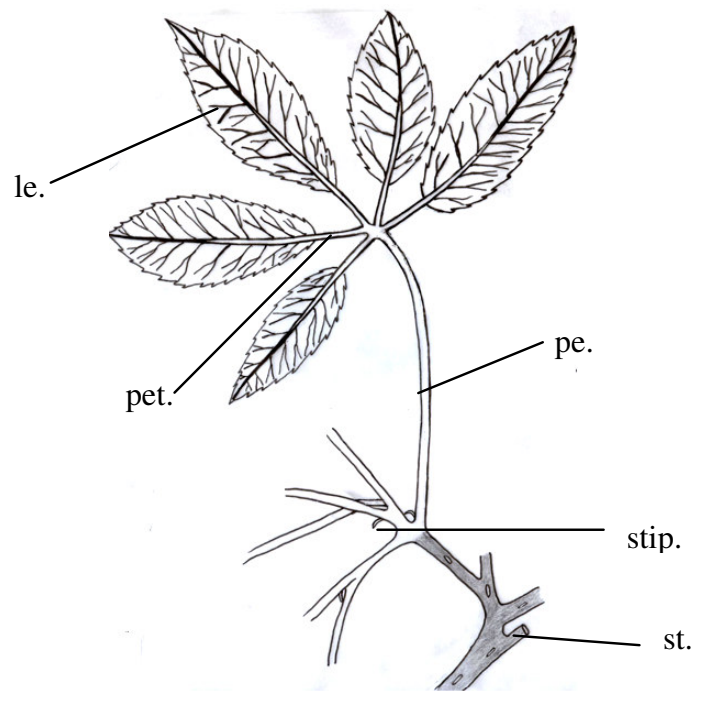

Fig. 2: Macromorphology of the aerial parts of the plant $\quad \mathrm{x} 0.3$.

le., leaflet; pe., petiole; pet., petioleole; st., stem; stip., stipule.

\section{B- Micromorphology \\ 1- The lamina of the leaflet (Fig. 3A)}

A transverse section in the leaflet is biconvex in outline which is more prominent in the lower surface. It shows a dorsiventral structure $^{13}$ with two rows of palisade cells. The palisade is interrupted in the midrib region by a collenchymatus mass. There are two vascular bundles, the first one is inverted and the lower one is crescent shape which consists of two arches of phloem and xylem, surrounded by parenchymatous pericycle interrupted by patches of pericyclic fibres. A larger lower mass of collenchyma cells is also present above the lower epidermis. Clusters of calcium oxalate as well as starch granules are scattered in the mesophyll and the cortical tissue. Mucilage cavities are scattered mainly near the lower surface. Both glandular and non glandular hairs are present only in the neural epidermis. 

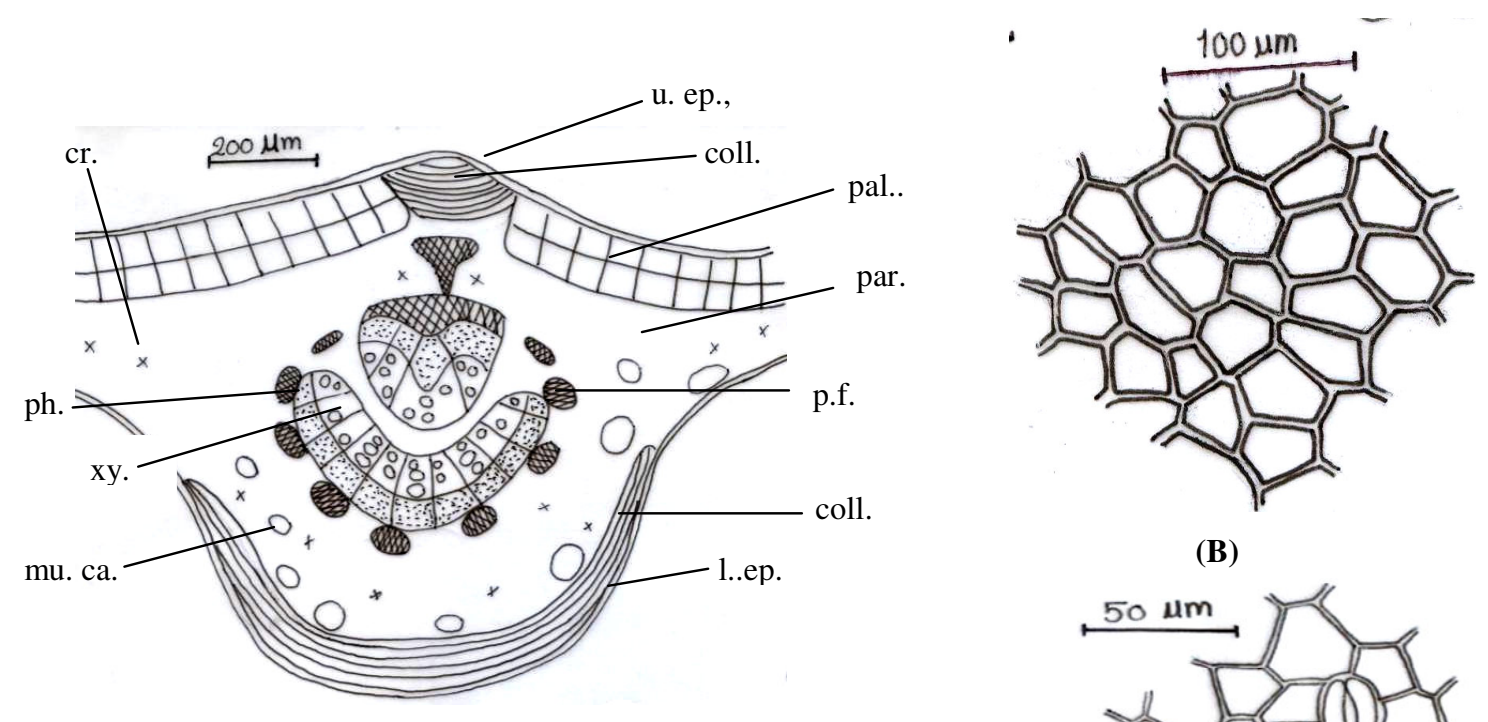

(A)

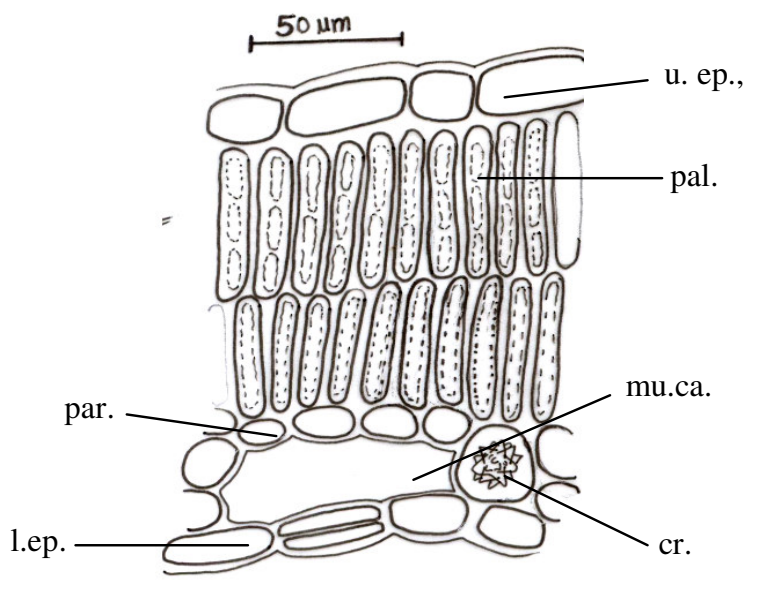

st.

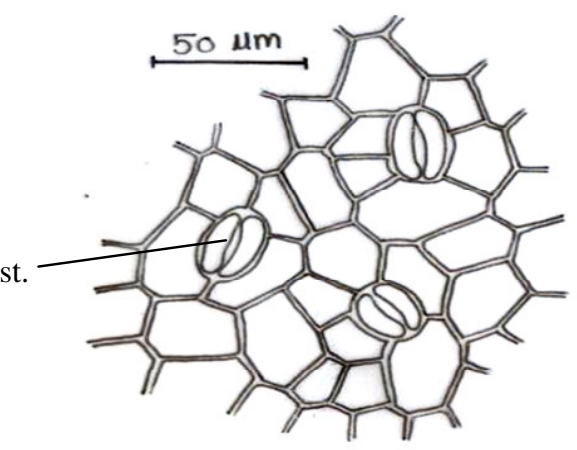

(D)

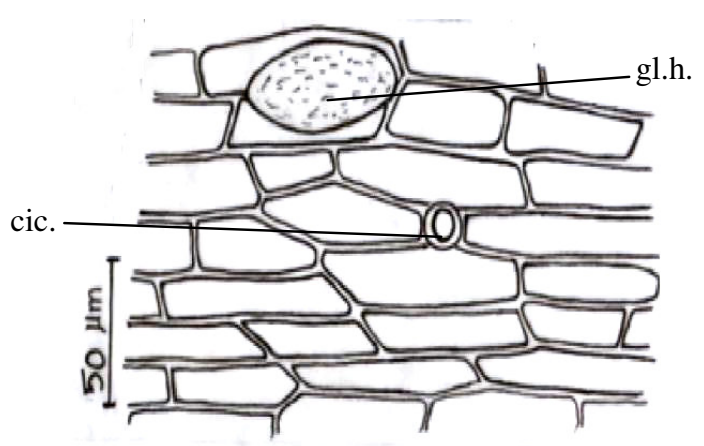

(E)

Fig. 3: A) The diagrammatic T.S of the midrib of the leaflet.

B) The upper epidermis of the leaflet.

C) T.S. of the lamina of the leaflet.

D) The lower epidermis of the leaflet.

E) The neural epidermis.

cic., cicatrix; coll., collenchyma; cr., crystal; gl.h., glandular hair; l.ep., lower epidermis; mu. ca., mucilage cavity; pal., palisade; par., parenchyma; ph., phloem; u.ep., upper epidermis; xy., xylem. 


\section{The epidermis}

Upper epidermis: In transverse section the upper epidermis (Figs. 3C and 4) consists of one row of square to subrectangular cells, while, in surface view (Fig. 3B) they appear polygonal with straight anticlinal walls. The cells are covered with thin smooth cuticle. Stomata and hairs are absent.

Lower epidermis: In transverse section, the lower epidermis (Figs. 3C and 4) consists of one row of square to subrectangular cells, While in surface view (Fig. 3D) the cells appear polygonal, showing straight anticlinal walls. The cells are covered with smooth cuticle and showing anomocytic type of stomata. Sometimes they are divided horizontally specially in the lamina. Hairs are absent ${ }^{13}$.

Neural epidermis: (Figs. 3E and 7) is long, axially elongated with more straight anticlinal walls and covered with thin smooth cuticle. The stomata are absent. Abundant trichomes are present of both covering and glandular types. The covering trichomes are unicellular. They are conical in shape with wide lumina, with acute to acuminate bent apices. The glandular trichomes have unicellular head and multicellular stalk of 4-6 cells.

\section{The mesophyll (Fig. 3C)}

The leaf is dorsiventral showing two rows of palisade which is followed by spongy tissue. The palisade is formed of cylindrical columnar cells containing chloroplasts closely packed. The spongy tissue is formed of thin walled, polygonal to rounded parenchymatous cells showing clusters of calcium oxalate and mucilage cavities (identified by testing with rethenium red).

\section{The cortical tissue (Fig. 4)}

Both the upper and the lower epidermis are formed of one row of square to subrectanglar cells. They are followed by a mass of collenchyma cells which is formed of 4-5 rows which are nearly rounded and cellulosic followed by 4-6 rows of parenchyma cells. Some of these cells contain clusters of calcium oxalate and others contain rounded starch granules (give blue color with iodine. Mucilage cavities are scattered between the parenchyma. The endodermis is indistinct.

\section{The pericycle (Figs. 3A \& 4)}

The pericycle exhibits nearly continous ring of fibres interrupted by parenchymatous cells which are slightly lignified.

\section{The vascular system (Figs. 3A \& 4)}

It is represented in the midrib region by an arc of vascular tissue showing xylem and phloem.

\section{The phloem}

It is formed of a narrow zone of soft small thin walled cellulosic elements, phloem parenchyma and bi-seriate non lignified medullary rays.

The cambium: It is indistinguishable.

\section{The xylem}

The xylem region consists of radial rows of lignified vessels, wood fibres, tracheides, medullary rays and wood parenchyma. The xylem vessels (Fig. 7) show spiral and reticulate thickening. The wood fibres are elongated with lignified walls showing narrow lumina and with blunt ends. The tracheids showed bordered pitted lignified thickening. The wood parenchyma consists of rectangular to subrectangular lignified cells. The xylem vessels are traversed by bi- and triseriate rectangular medullary rays, the upper ones in xylem region are non lignified while the lower ones are lignified.

\section{2- The petiole}

A transverse section in the petiole, (Fig. $5 \mathrm{~A})$ appears more or less rounded in outline. It has an outer epidermis covered with thin smooth cuticle followed by a mass of collenchyma then comparatively wide parenchyma containing abundant mucilage cavities and many clusters of calcium oxalate. The pericycle consists of patches of fibers which forms a circle surrounds the vascular bundle and interrupted by parenchyma cells. The vascular system is formed of a circle of phloem surrounds the xylem. 


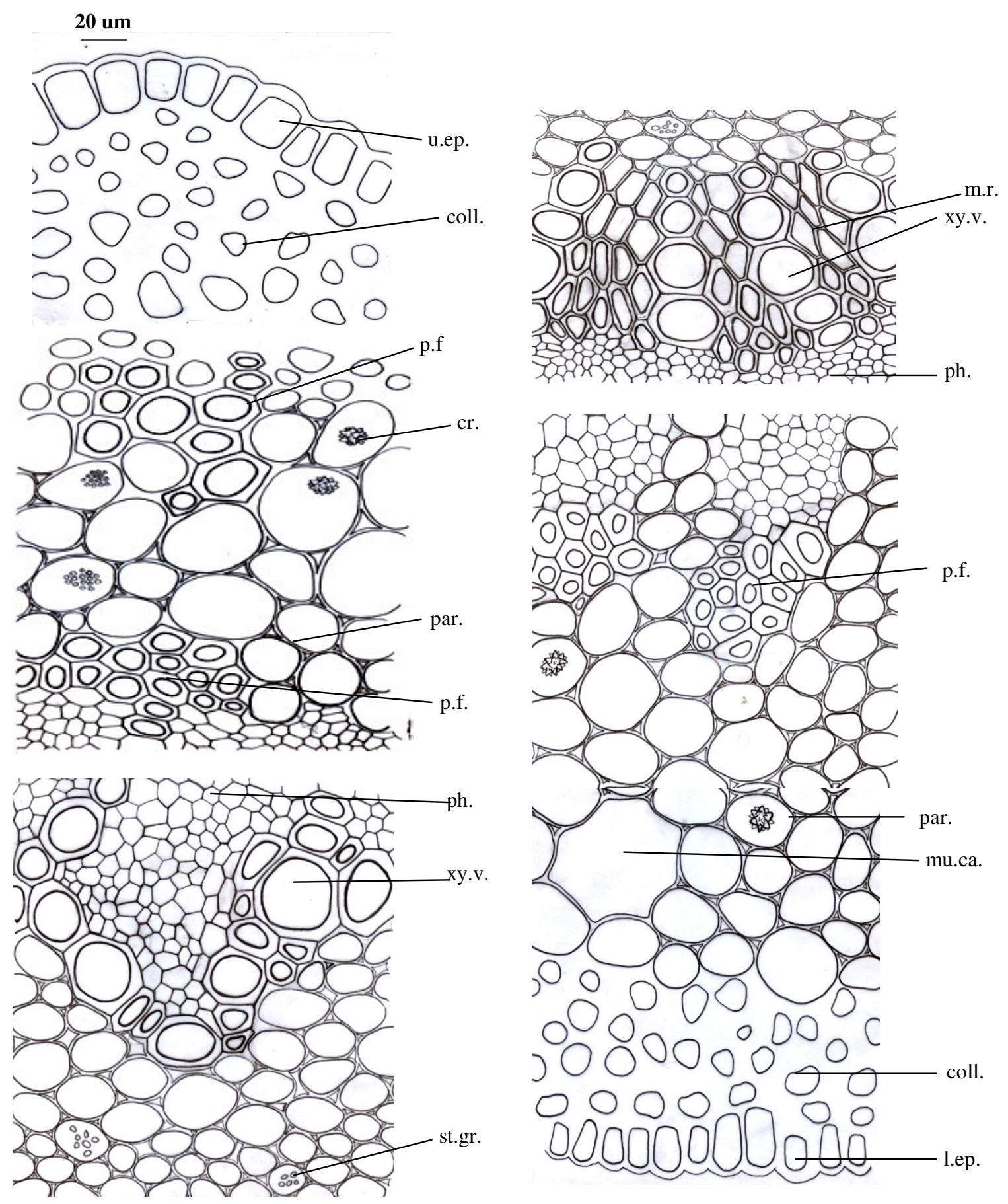

Fig. 4: The detailed T.S. of the leaflet.

coll., collenchyma; cr., crystal; l.ep., lower epidermis; m.r., medullary ray; mu.ca., mucilage cavity; par., parenchyma; ph., phloem; p.f., pericyclic fibre; st.gr., starch granules; u.ep., upper epidermis; xy.v., xylem vessel. 


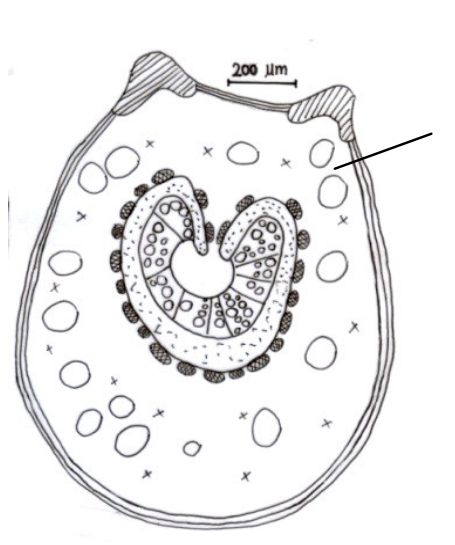

(B)

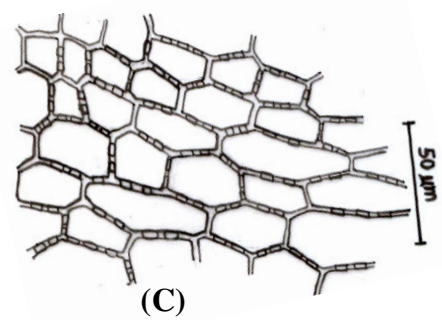

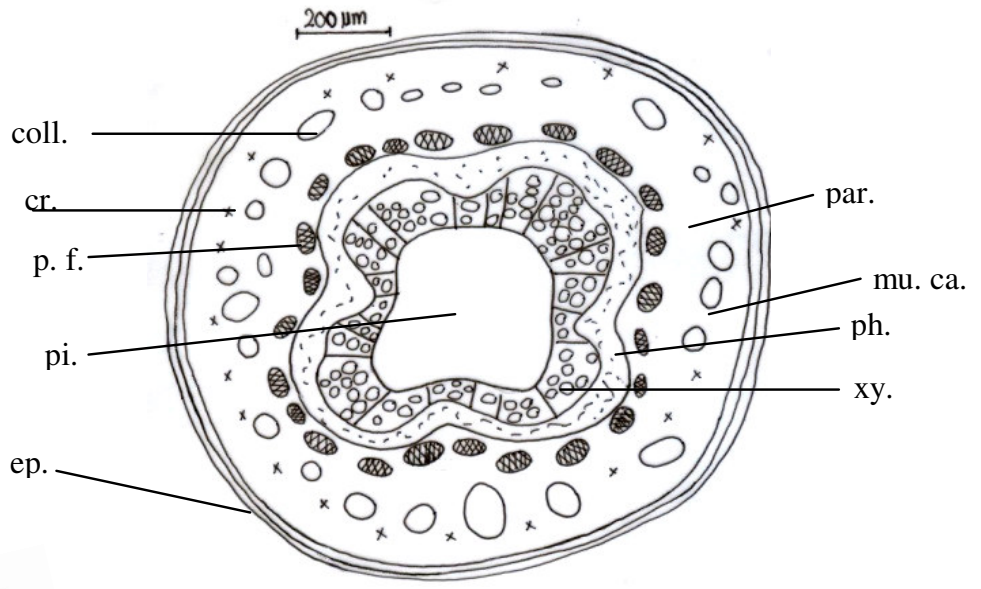

(A)

Fig. 5: A) The diagrammatic T.S of the petiole.

B) The diagrammatic T.S of the petioleole.

C) The epidermal cells of the petiole.

coll., collenchyma; cr., crystal; mu.ca., mucilage cavity; p.f., pericyclic fibre; par., parenchyma; ph., phloem; pi., pith; xy.v., xylem vessel.

\section{The epidermis}

It consists of one row of square to subrectangular cells as seen in transverse section (Fig. 6), while in surface view (Fig. 5C) they appear polygonal, with straight beaded anticlinal walls. The cells are covered with thin smooth cuticle. Stomata are not observed.

\section{The cortical tissue (Fig. 6)}

The cortical tissue is formed of about 4-5 layers of collenchymatous cells, followed by a wide parenchymatous layer of about 7-8 rows. Some of these cells contain clusters of calcium oxalate. Mucilage cavities are scattered.

Endodermis: It is not distinct.

\section{The pericycle (Fig. 6)}

The pericycle exhibits nearly continous ring of fibres interrupted by parenchymatous cells. The fibres have moderately thick, lignified walls and relatively narrow lumina.

\section{The vascular system (Figs. 6 and 7)}

The vascular system is formed of a large collateral vascular strand.

The xylem: consists of radial rows of lignified spiral and reticulate vessels, tracheids wood fibres and wood parenchyma.

The phloem: forms a ring of soft elements surrounding the xylem. It is formed of small, thin walled cellulosic elements below the xylem.

The cambium: is indistinguishable.

Medullary rays: bi or tri-serrate, they are non lignified in the phloem region while they are lignified and sometimes non lignified in the xylem region.

\section{The pith (Fig. 6)}

It consists of pitted parenchyma cells with mucilage cavities. 


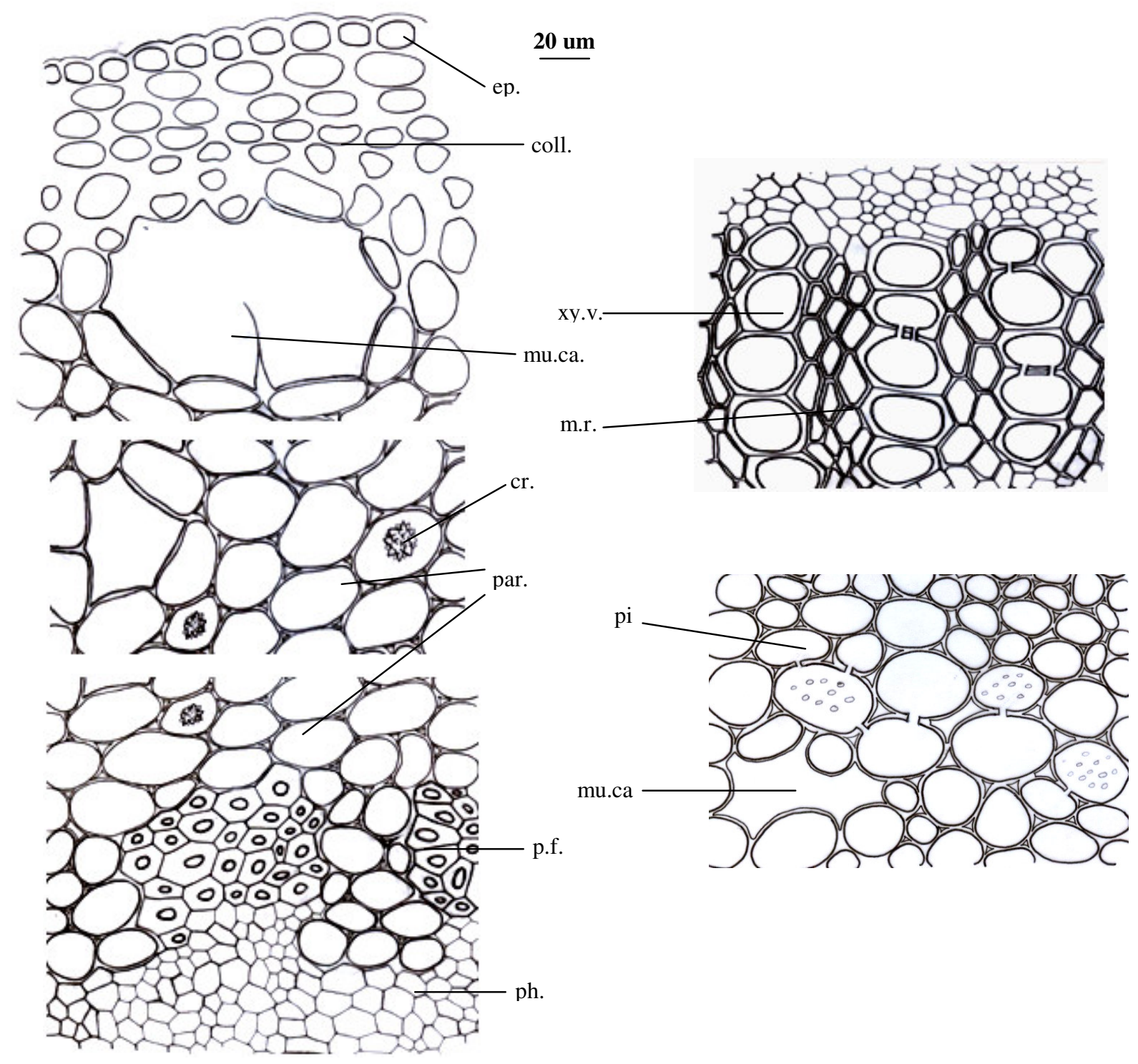

Fig. 6: The detailed T.S. of the petiole.

coll., collenchyma; cr., crystals of ca.ox.; e.p., epidemis; m.r., medullary rays; mu.ca., mucilage cavity; p.f., pericyclic fibre; par., parenchyma; ph., phloem; pi., pith; xy.v., xylem vessel.

\section{The petioliole (Fig. 5B)}

The transverse section is the same as the petiole but has 2 wings formed of collenchyma cells $^{14}$.

\section{The powdered leaflet and petiole (Fig. 7)}

The powdered leaflet and petiole is green in colour, odorless and has a mucilagenous taste. It is characterized microscopically by the following:

1- Fragments of the upper epidermal cells of the lamina.
2- Fragments of lower epidermal cells of the lamina.

3- Fragments of the epidermal cells in the midrib region (neural epidermis).

4- Fragments of columnar palisade cells.

5- Fragments of lignified xylem vessels with spiral and reticulate thickening.

6- Scattered clusters of calcium oxalate either free or embedded in parenchyma cells of the cortical tissue.

7- Fragments of lignified tracheids in both leaf and petiole which are reticulated and pitted. 


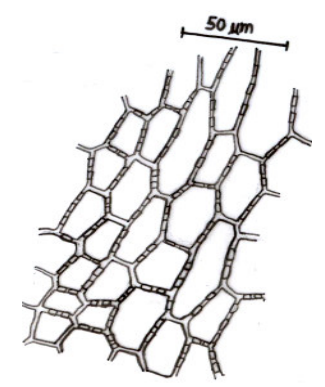

ep.pet.

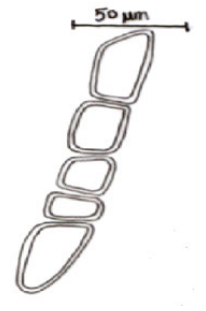

m.r.

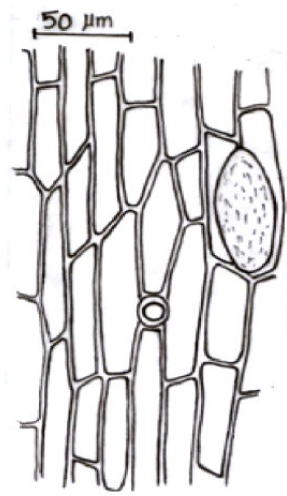

ne.ep.

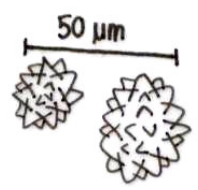

cr.

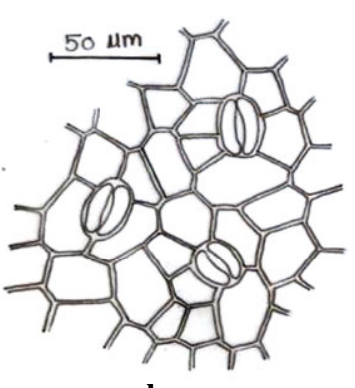

l.ep.

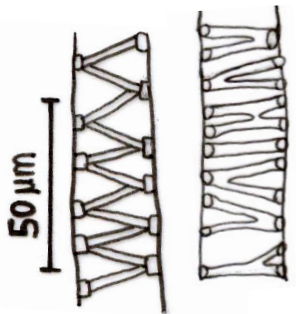

xy.v.

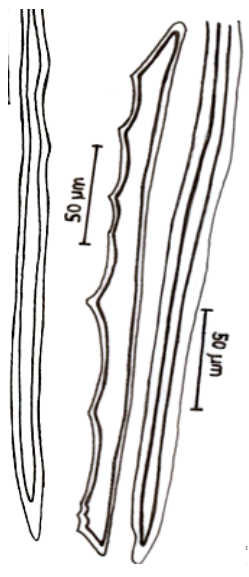

p.f. w.f.

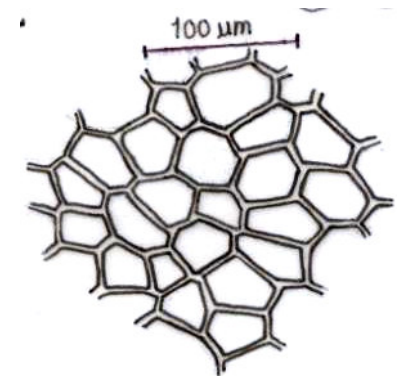

pal.

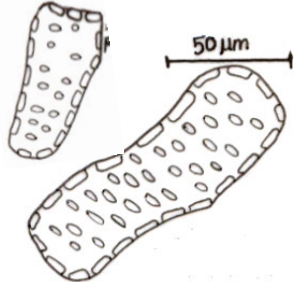

w.par.

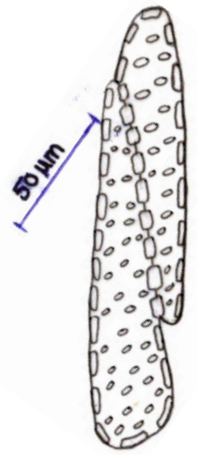

tr. up.ep.

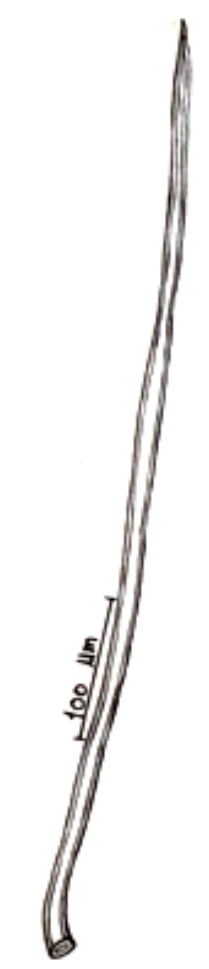

n.gl.h.ne.

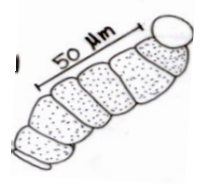

gl.h.ne.

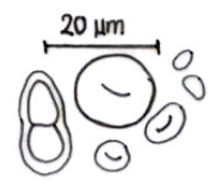

st.gr.

Fig. 7: Powder of the leaf.

cr., crystals; ep.pet., epidermis of petiole; gl.h.ne., glandular hair of the neural epidermis; 1.ep., lower epidermis; m.r., medullary ray; n.gl.h.ne., non-glandular hair of the neural epidermis; ne.ep., neural epidermis; p.f., pericyclic fiber; pal., palisade; st.g., starch granules; tr., tracheides; u.ep., upper epidermis; w.f., wood fiber; w.p., wood parenchyma; xy.v., xylem vessel. 
8- Few starch granules which are mainly simple and rarely semi-compound, with cleft centric hilum, present either free or in parenchyma cells.

9- Fragments of the epidermal cells from the petiole.

10- Fragments of pericyclic fibres which are lignified, with dentate walls, nearly wide lumina and blunt ends.

11- Fragments of wood fibres which are lignified, with narrow lumina and blunt ends.

12- Fragments of wood parenchyma which have lignified and pitted walls.

13- Fragments of non glandular and glandular hairs from the neural epidermis.

14- Fragments of the medullary rays which are nearly square in shape, some of them lignified and others are not.

\section{THE STEM}

\section{A- Macromorphology (Fig. 2A \& B)}

The main stem and old branches are cylindrical, measuring up to $10 \mathrm{~cm}$ in diameter, woody and brown in colour. The surface is rough, showing several spines which increase in size by aging, sometimes falling leaving brownish circular or oval scars with short internodes. The direction of growth is erect.
The young branches are also woody, measuring about $1 \mathrm{~cm}$ in diameter, brown in colour. They break with slightly hard fibrous fracture exposing uneven yellowish white fibrous cut surface ${ }^{14}$.

The branching is monopodial. In old trees the main trunk shows swelling that increases in size by aging. The stem is odourless and has a mucilagenous taste.

\section{B- Micromorphology \\ 1- Young stem (Fig. 8A)}

A transverse section in the young stem is more or less circular in outline showing epidermis then a wide parenchymatous cortex. The pericycle consists of wide patches of lignified fibres. Then the central cylinder is formed of a complete ring of vascular elements, enclosing wide pith. The phloem region is narrow while the xylem region is comparatively wide, with a primary xylem toward the pith and being separated from the phloem by a zone of cambiform cells. The phloem and the xylem are radially traversed by numerous medullary rays. Numerous clusters of calcium oxalate and mucilage cavities are present in the parenchyma of the cortex and pith and prisms of calcium oxalate are found in the medullary rays.

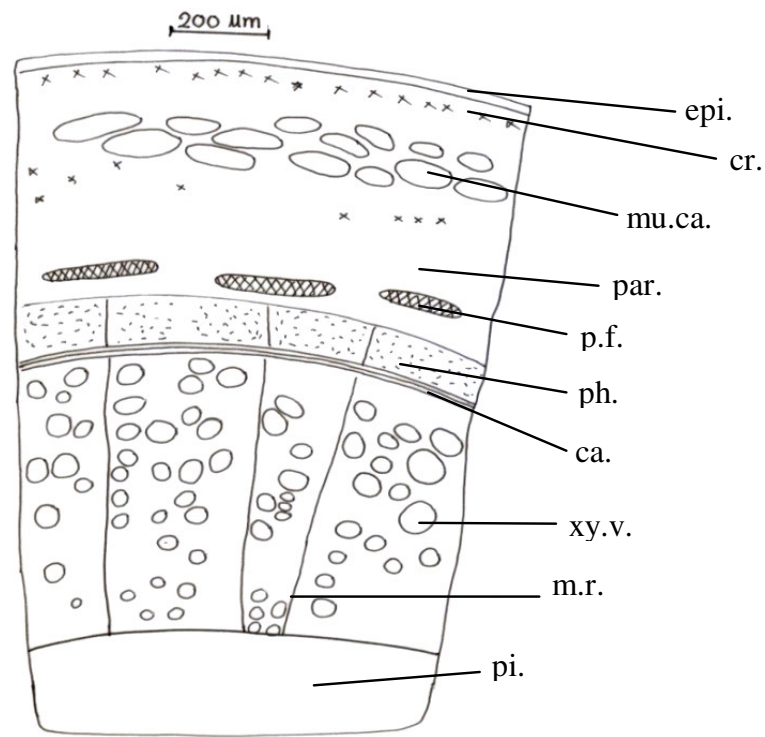

(A)

Fig. 8: A) The diagrammatic T.S. of the young stem.

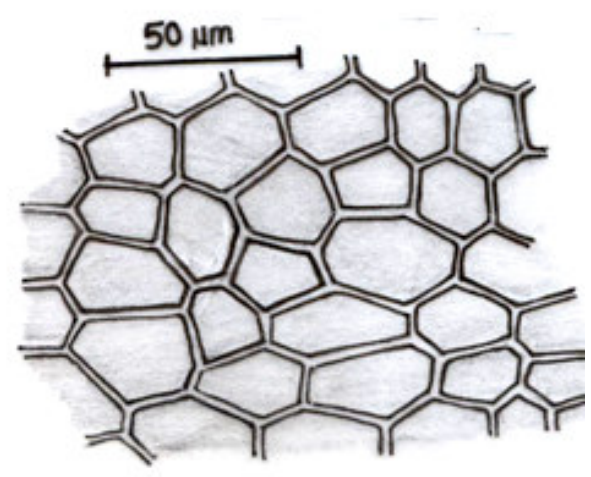

(B)

B) The epidermal cells of the young stem.

ca., cambium; cr., crystals; epi., epidermis; hyp., hyodermis; m.r., medullary ray; mu.ca., mucilage cavity; par., parenchyma: p.f., pericyle; ph., phloem; pi., pith; xy.v., xylem vessels. 


\section{The epidermis}

The epidermis consists of one layer of square to subrectangular cells in T.S. (Fig. 9). In surface view (Fig. 8B) the cells are subrectangular, mainly isodiammetric with straight anticlinal walls and have brownish contents. There are no stomata or hairs.

\section{The cortex (Fig. 9)}

It is a very wide layer composed of rounded parenchyma. The cells contain many clusters of calcium oxalate and numerous mucilage cavities.

\section{The pericycle (Figs. 9 and 10)}

It consists of wide patches of lignified fibers. These fibers have pointed and acuminate ends with relatively thick lignified walls and comparatively very narrow lumina.

\section{The vascular system (Fig. 9)}

It shows a wide continuous ring traversed by narrow medullary rays and it is formed mainly of secondary elements.

\section{The phloem}

It is formed of a narrow ring, consisting of shining thin walled soft, cellulosic elements of sieve tubes, companion cells and thin walled phloem parenchyma.

\section{The cambium}

It is formed of 3-4 rows of cellulosic thin walled cambiform cells, which are subrectangular, tangentially and radially arranged.

\section{The secondary xylem}

It consists of lignified, pitted and thick walled radially arranged elements. It consists of large vessels, wood fibers, tracheids, tracheidal vessels and wood parenchyma (Fig. 10). The wood parenchyma occurs usually in vertical rows and the cells are subrectangular. The medullary rays are usually biserriate to triserriate. In the xylem region, the cells of medullary rays are radially elongated, subrectangular with thick, pitted lignified walls showing prisms of calcium oxalate but in the phloem region they are non-lignified thin walled parenchyma. The wood fibers have wide lumina, thick walls and blunt to rounded ends.

\section{The primary xylem}

It is formed of few lignified xylem vessels.

\section{The pith (Fig. 9)}

It is wide, parenchymatous, consisting usually of large, polygonal to rounded, isodiametric cells with lignified walls. It contains cluster crystals of calcium oxalate as well as mucilage cavities.

\section{The powder of young stem}

The powder of young stem (Fig. 10) has light brown colour, mucilagenous taste and odourless.

It shows the following fragments:

1- Fragments of the epidermal cells.

2- Fragments of pericyclic fibers which are relatively thick refractive walls and narrow lumina. Their ends are pointed and acuminate.

3- Fragments showing reticulate and spiral xylem vessels.

4- Fragments showing lignified pitted wood parenchyma.

5- Fragments showing lignified reticulated tracheids.

6- Occasional prismatic and cluster crystals of calcium oxalate either free or enclosed in parenchymatous cells.

7- Fragments of wood fibers which have wide lumina, thick walls and blunt to rounded ends.

8- Few starch granules.

\section{2- Stem bark}

\section{Macromorphology (Fig. 11)}

The stem bark is curved and slightly concave on the inner side measuring $1 \mathrm{~cm}$ in width and $0.1 \mathrm{~cm}$ in thickness. It has fibrous fracture. The outer surface exhibits longitudinal ridges and furrows and shows lenticels while the inner surface is pale brown in colour and striated.

In younger trees, the bark is bright green due to high content of chlorophyll and is capable of performing photosynthesis when leaves are shed. However, with age as the girth of the trunk widens, patches of newer grey bark appear as ridges and finally becomes entirely grey. The stem and branches are covered with conical prickles, which fall off as the tree grows older ${ }^{14}$. 


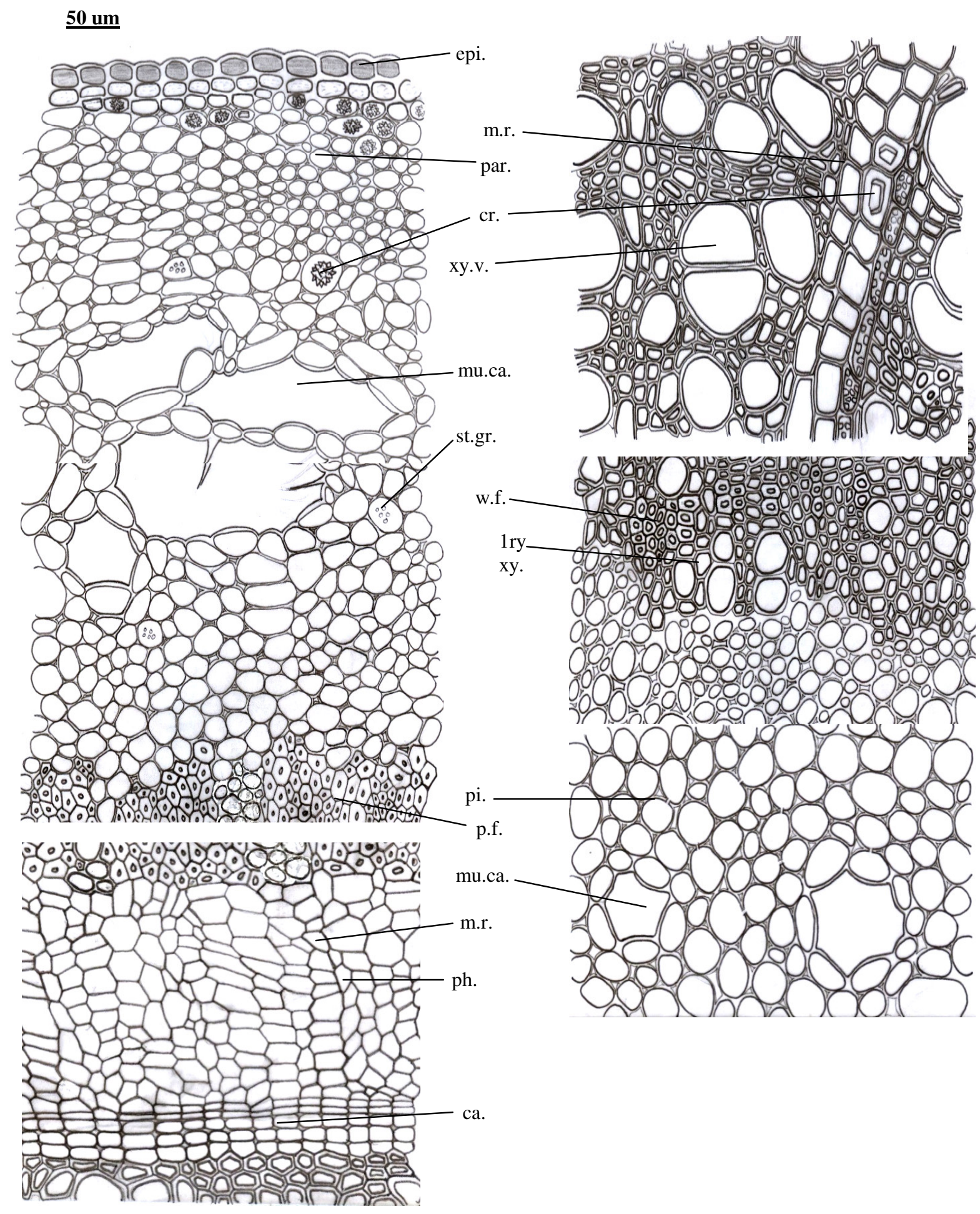

Fig. 9: The detailed T.S. of the young stem.

1ry xyl., primary xylem; ca., cambium; cr., crystals; epi., epidermis; hyp., hypodermis; m.r., medullary ray; mu.ca., mucilage cavity; par., parenchyma; st.gr., starch granules; p.f., pericyle; ph., phloem; pi., pith; w.f., wood fibre; xy.v., xylem vessels. 


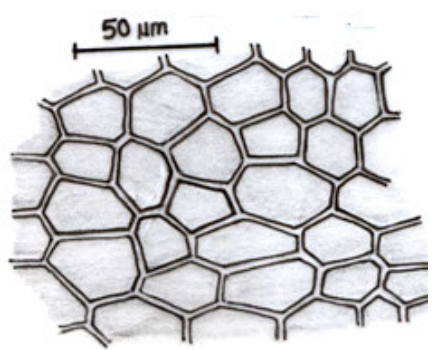

ep.

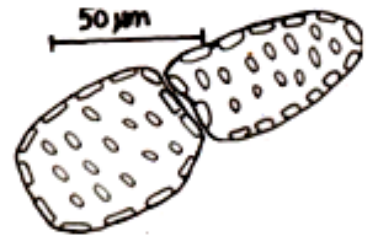

w.par.

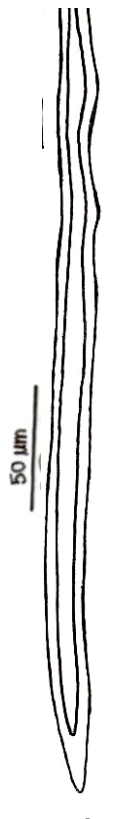

p.f.

tr.

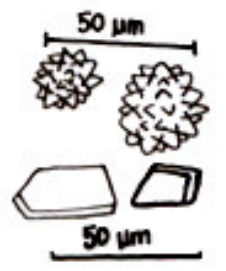

cr.

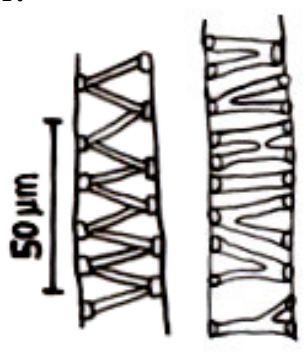

xy.v.

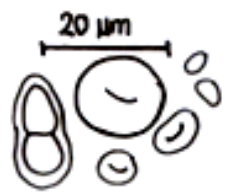

st.gr.

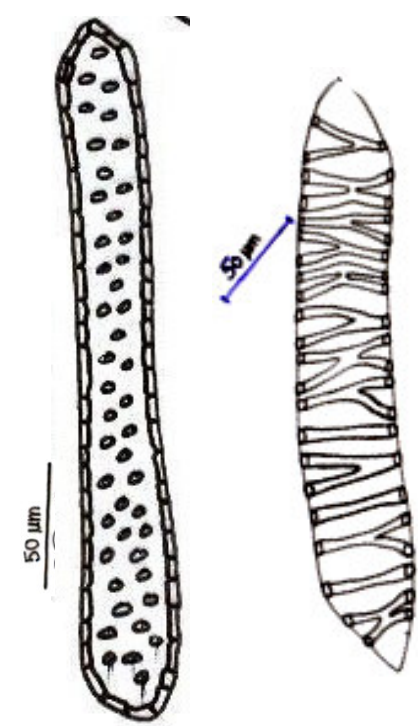

w.f.

Fig. 10: Powder of the young stem.

cr., crystals of ca.ox.; ep., epidermis of the young stem; p.f., pericyclic fiber; st.gr., starch granules; tr., tracheides; w.f., wood fiber; w.par., wood parenchyma; xy.v., xylem vessel.

The stem bark is odourless and has a mucilagenous taste.

\section{Micromorphology (Fig. 12A)}

A transverse section in the stem bark shows cork cells with brown and thick walls, followed by chlorenchymatous cells, Then, a very wide layer of sclerides, followed by the pericycle with patches of fibres and finally very wide layer of the phloem with its fibres and traversed by numerous medullary rays.

\section{The cork}

The cork consists of several, rows of subrectangular cells, tangentially elongated and arranged in radial rows with brown and thick 
walls (Fig. 13). In surface view (Fig. 12B), they

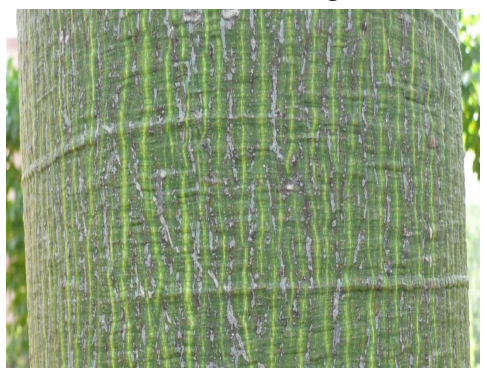

(A)

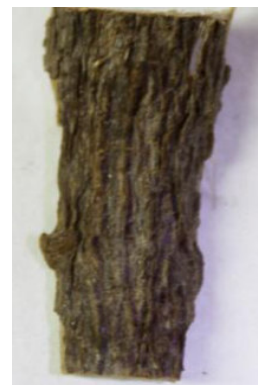

a

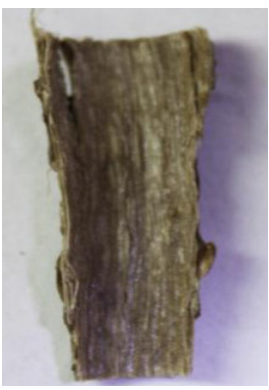

b

(C) appear polygonal and mainly isodiametric.

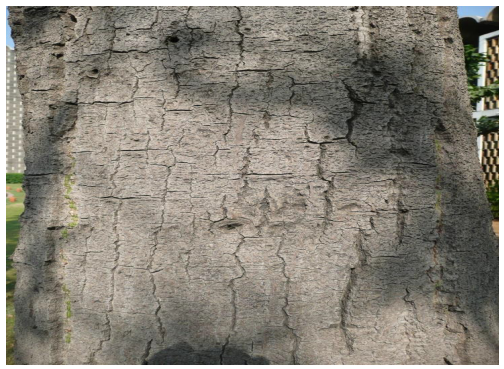

(B)

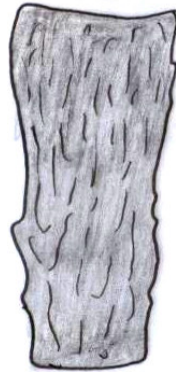

a

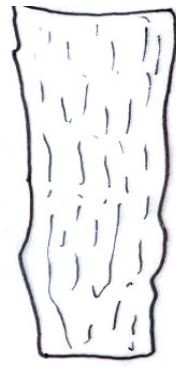

b
(D)

Fig. 11: A) A photo of the bark in the young tree

$\mathrm{x} 0.2$.

B) A photo of the bark in the old tree

$\mathrm{x} 0.2$.

C) $a \&$ b: A photo of the outer and inner surfaces of the stem bark respectively

D) a \& b: The outer and inner surfaces of the stem bark respectively $\mathrm{x} 0.5$.

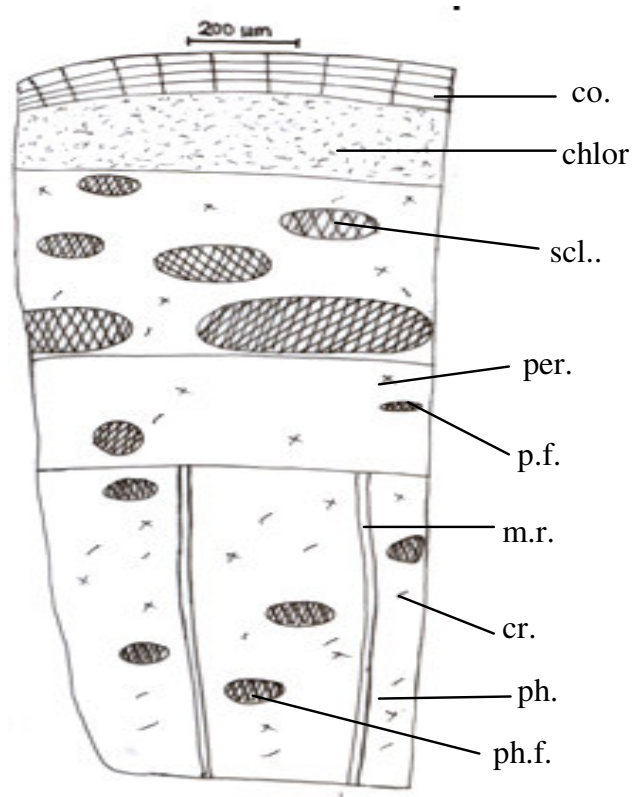

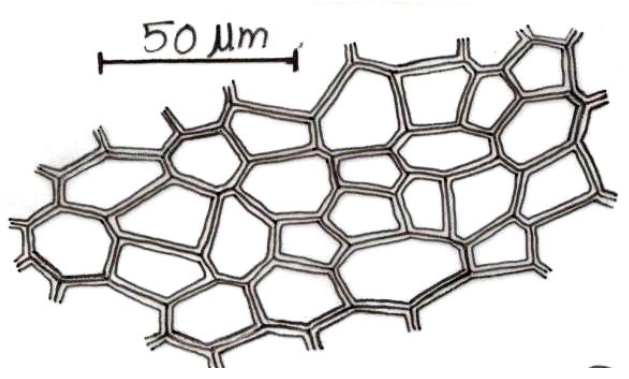

(B)

(A)

Fig. 12: A) The diagrammatic T.S of the stem bark.

B) The cork cells. 
chlor., chlorenchyma; co., cork; cr., crystal; m.r., medullary rays; p.f., pericyclic fibre; par., parenchyma; per., pericycle; ph.f., phloem fibre; ph., phloem; scl., sclerides.

\section{The chlorenchyma (Fig. 13)}

It consists of several rows of parenchyma cells containing chloroplasts that are responsible for the green color of the bark in the young trees.

\section{The sclerides (Fig. 13)}

There are a wide zone of sclerides with few parenchyma cells in between containing prisms of calcium oxalate.

The sclerides are two types: the first group of 5-6 layers of oval pitted thin lignified walls and wide lumina, while the second group of 2-3 layers of elongated thick lignified walls and very narrow lumina.

\section{The pericycle (Fig. 13)}

It forms a wide layer of parenchyma cells containing prisms and cluster crystals of calcium oxalate interrupted by patches of pericyclic fibres which are lignified and have narrow lumina.

\section{The phloem (Fig. 13)}

A very wide layer That consists of shining thin walled soft, cellulosic elements of sieve tubes, companion cells, phloem parenchyma which are large and collapsed cells containing prisms and clusters of calcium oxalate and groups of phloem fibres which have relatively narrow lumina, thick and lignified walls.

\section{The medullary rays (Fig. 13)}

They are mainly uniserriate sometimes biserriate. They are radially elongated, subrectangular, non-lignified thin walled cells containing prisms of calcium oxalate.

\section{The powder of stem bark}

It (Fig. 14) has greenish brown colour, odourless and mucilagenous taste.

It shows the following fragments:

1- Fragments of the cork cells.

2- Fragments of chlorenchyma cells.

3- Fragments of pericyclic fibers which are lignified, have narrow lumina with blunt to rounded ends and have dentate walls.

4- Prisms and cluster crystals of calcium oxalate.

5- Fragments of phloem fibers which are lignified and have relatively wide lumina and blunt apices.
6- Fragments of sclerides of two types:

The first type is oval with small lignified pitted walls and wide lumina while the second type has narrow lumina with thick lignified walls.

7- Fragments of chlorenchyma cells.

\section{THE FRUIT}

\section{Macromorphology (Fig. 15)}

The fruit is a simple, dry, dehiscent oblong-to- ellipsoid loculicide woody capsule and is derived from a superior gynaecium. It is green in colour, become brown on ripening. The fruit measures $8-20 \mathrm{~cm}$ in length and up to $8 \mathrm{~cm}$ in width and many seeds (100-150) are embedded in white silky floss fibres, which are dispersed by wind when the capsule splits along five sutures, much like the kapok. The silky floss develops from the inner wall of the fruit (and not from the seed coat).

The outer layer of the pericarp is thick, smooth and glabrous ${ }^{14}$.

\section{Micromporphology of the pericarp of the fruit (Fig. 16A)}

A transverse section in the pericarp is more or less circular in the outline, showing one layer of epicarp then a very wide parenchymatous mesocarp with numerous scattered vascular bundles.

\section{The epicarp}

The epicarp is thick and hard, formed of one layer of columnar compact palisade-like cells in transverse section (Fig. 17). In surface view (Fig. 16B) they are polygonal and have thick cellulosic straight anticlinal walls, covered with thin smooth cuticle. Stomata are absent.

\section{The mesocarp (Fig. 17)}

The mesocarp is formed of a layer of sclerides about 4-6 rows followed by parenchyma cells with slightly thick walls with mucilage cavities. It is traversed by numerous vascular bundles. The inner most layer of the mesocarp contains some clusters of calcium oxalate.

The sclereids are polygonal sometimes elongated, lignified, with wide lumina. 


\section{$50 \mathrm{um}$}
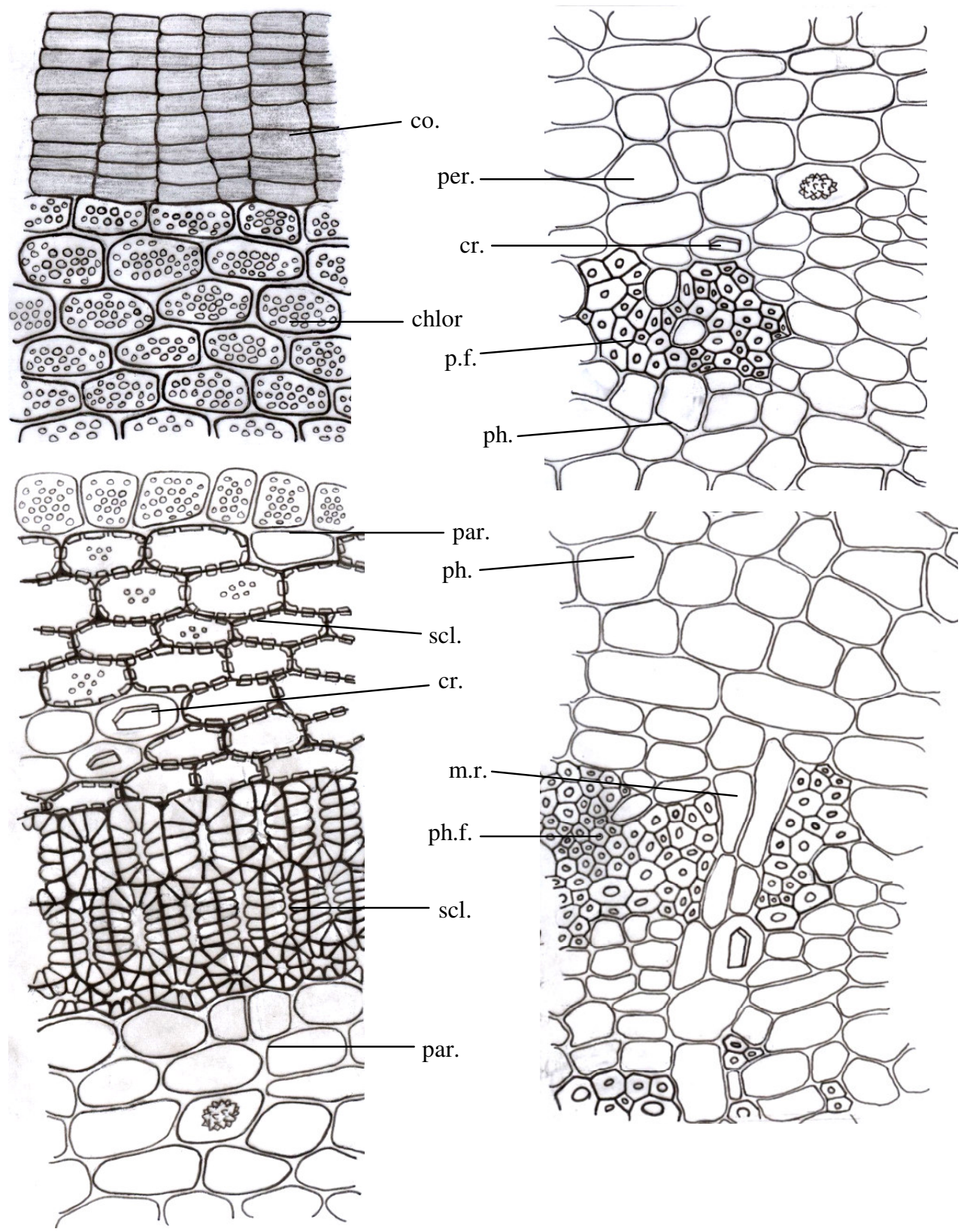

\section{(}

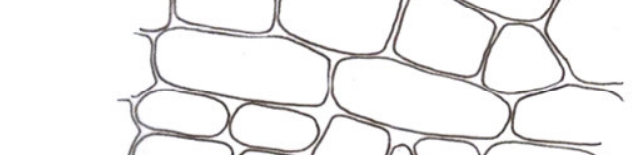

.r. -
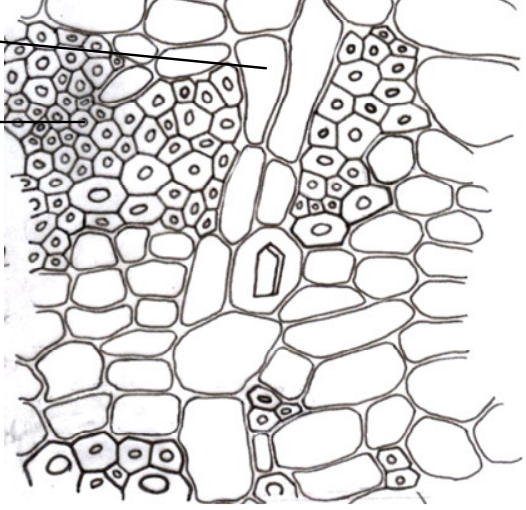

Fig. 13: The detailed T.S. of the stem bark.

chlor., chlorenchyma; co., cork; cr., crystal; m.r., medullary rays; p.f., pericyclic fibre; par., parenchyma; per., pericycle; ph., phloem; ph.f., phloem fibre; scl., sclerides. 

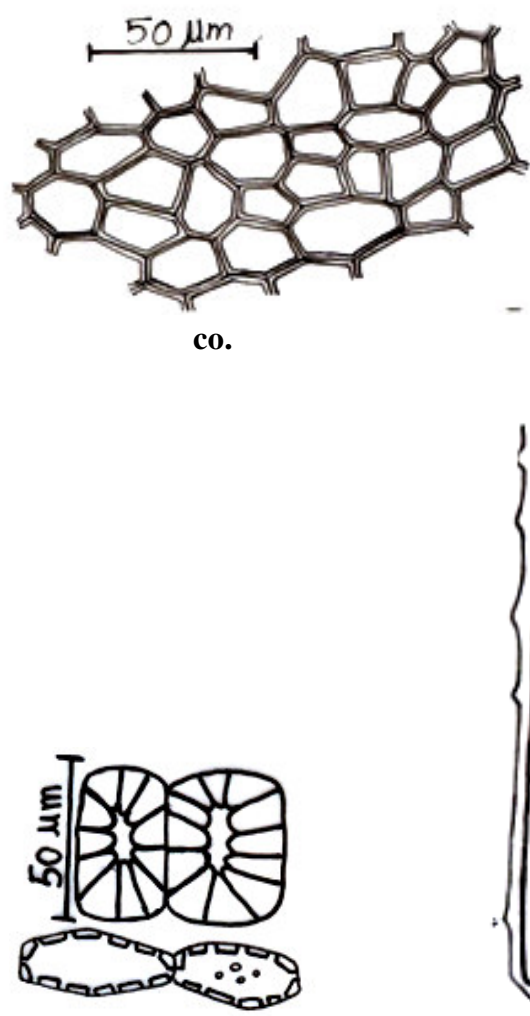

scl.

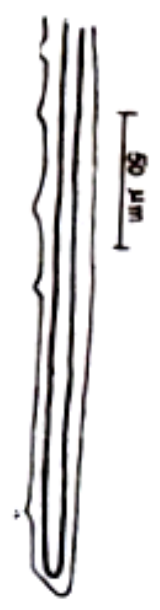

p.f.
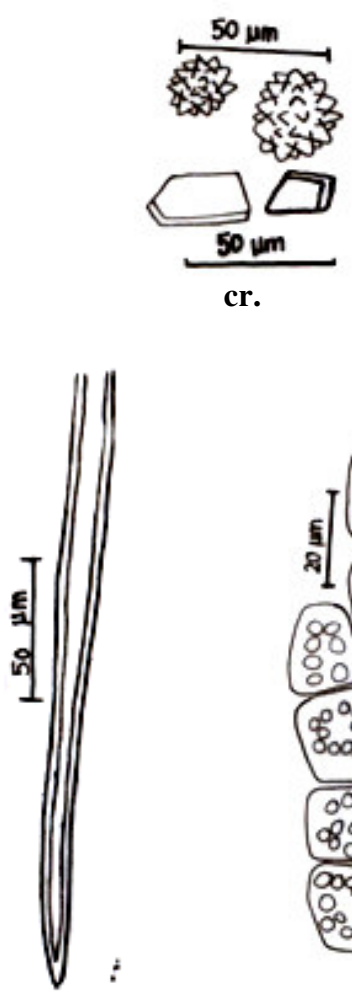

ph.f.

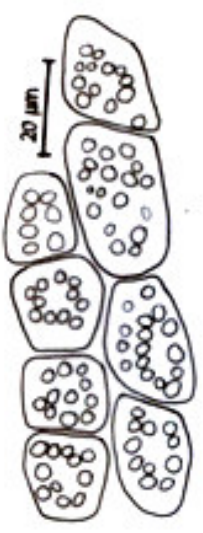

chlor.

Fig. 14: Powder of the stem bark.

chlor., chlorenchyma; co.,cork cells; cr., crystals of ca.ox.; p.f., pericyclic fiber; ph.f., phloem fibre; scl., sclerides.

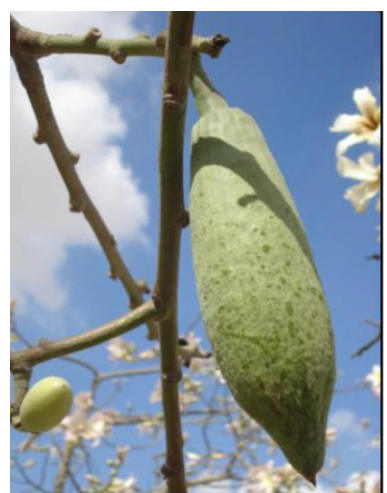

(A)

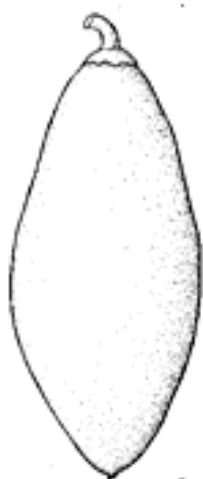

(B)

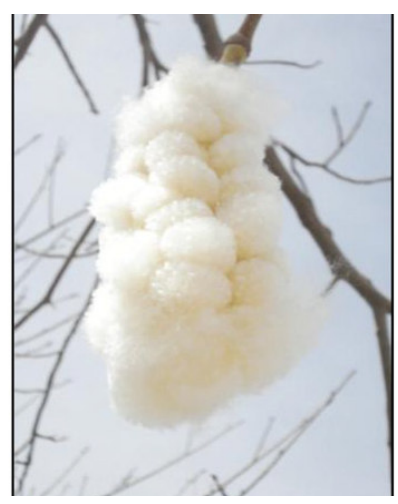

(C)

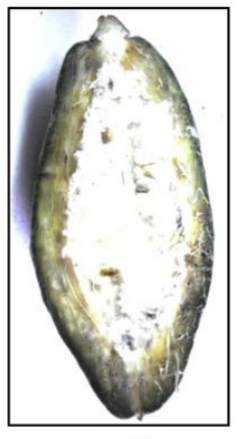

(D)

Fig. 15: A) A photo of the fruit

B) The fruit

C) A photo of the floss silk from the fruit

D) A photo of l.cut of the fruit

$x 0.3$.

$\mathrm{x} 0.3$.

$\mathrm{x} 0.4$.

$\mathrm{x} 0.3$. 

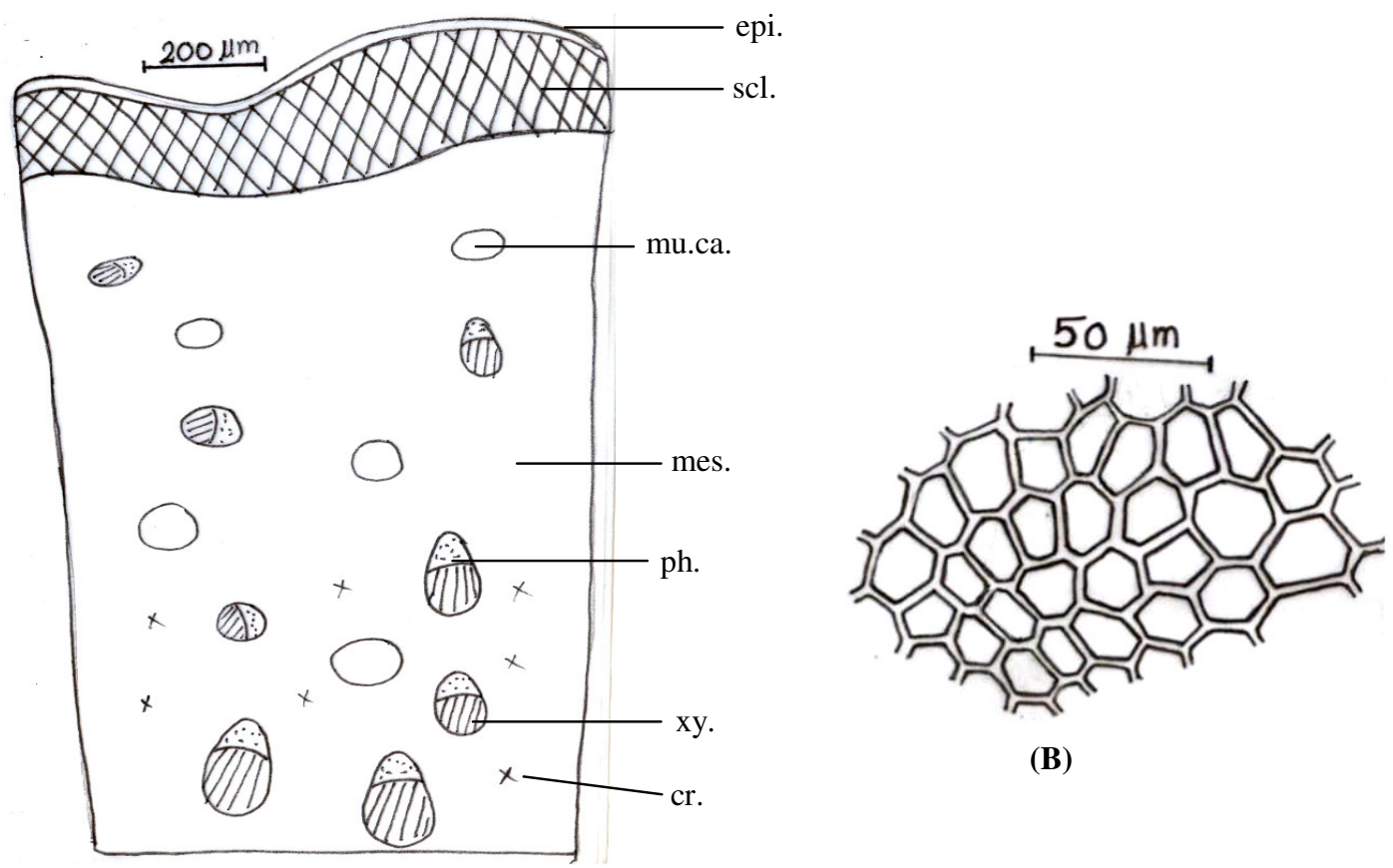

(B)

(A)

Fig. 16: A) A digrammitic T.S of the pericarp.

B) The epicarp.

cr., crystals of ca.ox.; ep., epicarp; par., parenchyma; mes., mesocarp; mu.ca., mucilage cavity; ph., phloem; scl., sclerides; xy., xylem.

\section{The vascular bundle (Fig. 17)}

It is collateral, formed of thin walled cellulosic soft elements of phloem and lignified xylem of indistinguishable elements.

\section{The endocarp (Fig. 17)}

It isn't distinguishable. The floss silk inside the endocarp forms a large mass surrounding each seed.

\section{The stalk of the fruit (Fig. 18A)}

The transverse section appears nearly circular in outline, showing parenchymatous cortex with numerous mucilage cavities and cluster crystals of calcium oxalate, followed by a wide vascular bundle surrounded by the pericycle.

\section{The cork}

The cork consists of about 4 rows of subrectangular cells (Fig. 19) with brown and thick walls. In surface view (Fig. 17B), they appear polygonal and mainly isodiametric.

\section{The cortex (Fig. 19)}

It is formed of rounded, small parenchyma cells which contain numerous clusters of calcium oxalate and few simple starch granules. Mucilage cavities are scattered.

\section{The pericycle (Fig. 19)}

It is formed of parenchyma cells and numerous patches of lignified pericyclic fibres with very narrow lumina.

\section{The vascular system (Fig. 19)}

\section{The phloem}

It is a wide region and formed of thin walled cellulosic soft elements of phloem parenchyma, sieve tubes and companion cells. Phloem fibres are also present which are lignified with narrow lumina. Medullary rays are wide, usually bi or triserrate, containing numerous cluster crystals of calcium oxalate. 
$\underline{50 \mathrm{um}}$

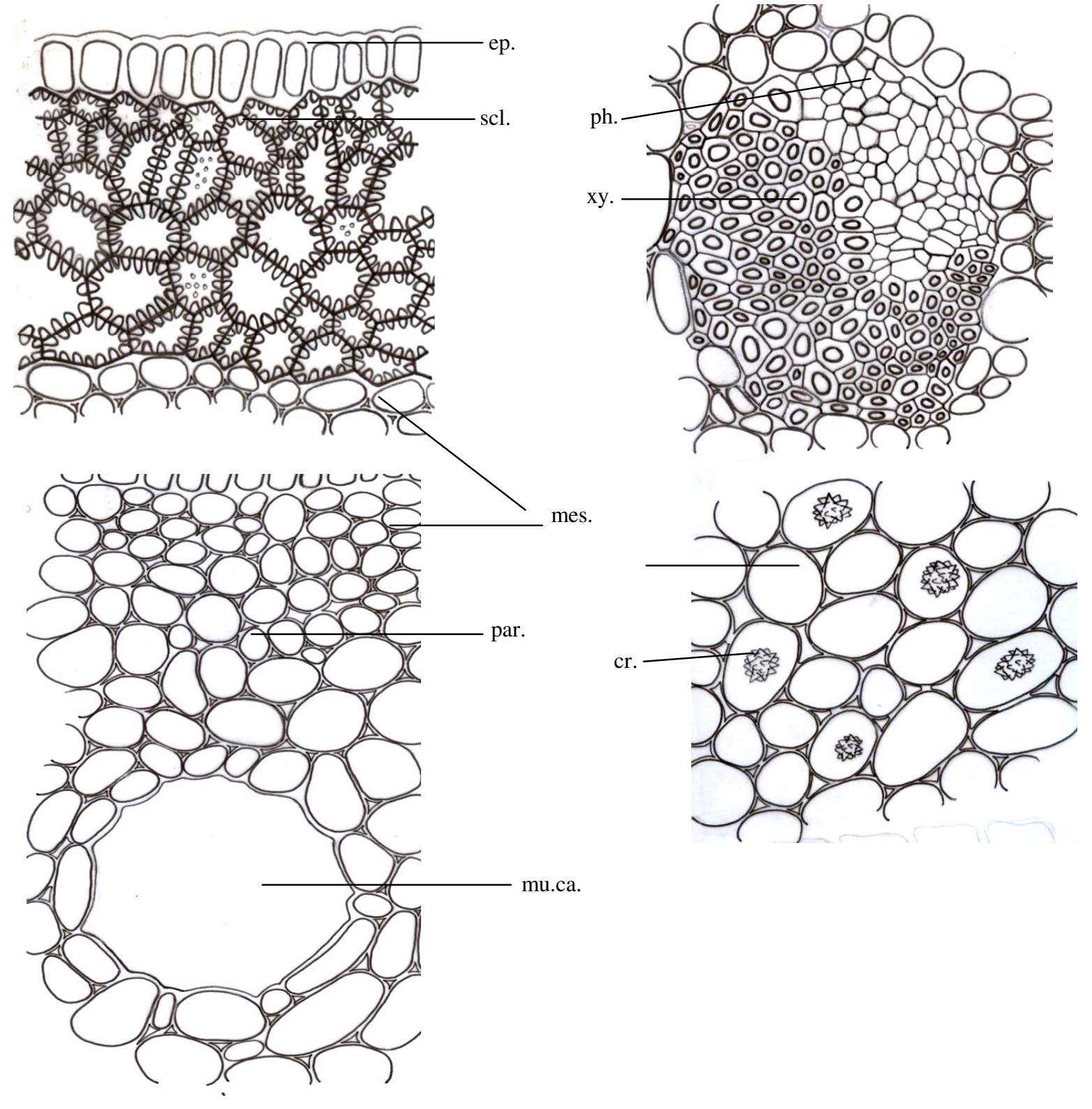

Fig. 17: The detailed T.S. of the pericarp.

cr., crystals of ca.ox.; ep., epicarp; par., parenchyma; mes., mesocarp; mu.ca., mucilage cavity; ph., phloem; scl., sclerides; xy., xylem. 


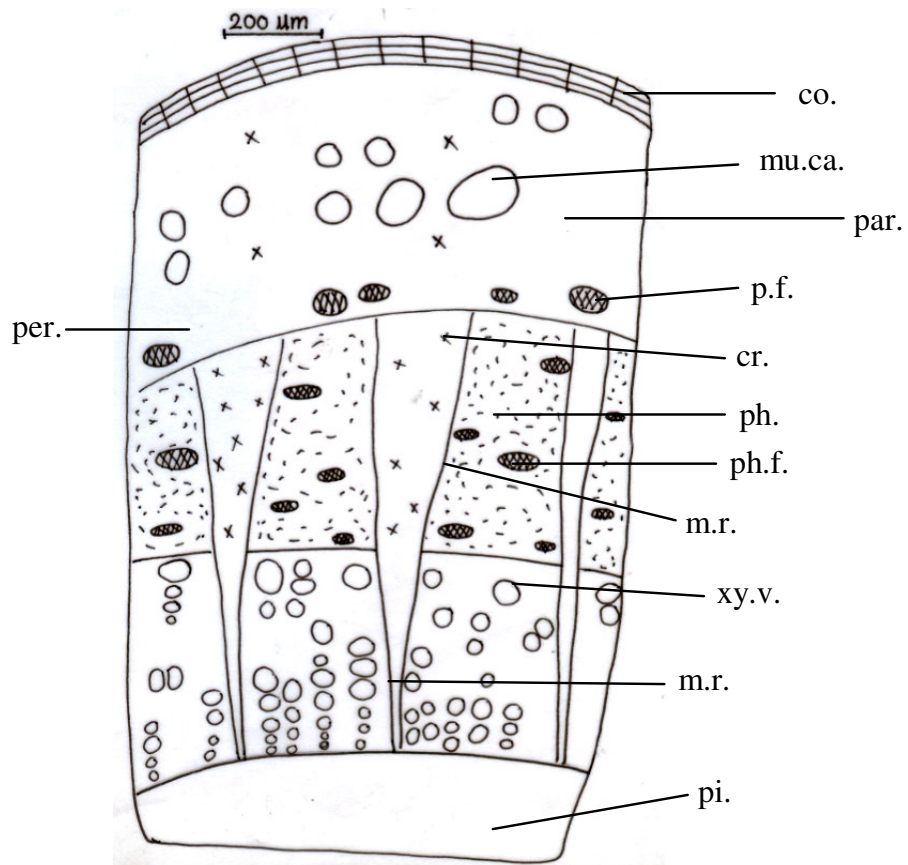

(A)

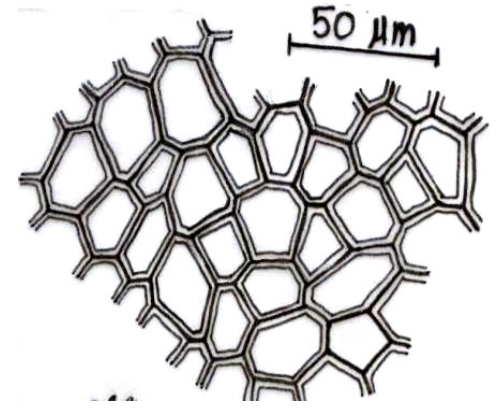

(B)

Fig. 18: A) The diagrammatic T.S of the stalk of the fruit.

B)The cork of the stalk of the fruit.

co., cork; cr., crystal; m.r., medullary rays; mu.ca., mucilage cavity; par., parenchyma; p.f., pericyclic fibre; per., pericycle; ph., phloem; ph.f., phloem fibre; pi., pith; xy.v., xylem vessels.

\section{The xylem}

It is also a wide region, It is formed of lignified vessels and lignified and non lignified wood parenchyma.

Medullary rays are smaller and narrower in size than that in the phloem region and they are also sometimes lignified and sometimes non lignified.

\section{The pith (Fig. 19)}

It is formed of wide parenchymatous layer some of them contain brownish contents. Prisms and clusters of calcium oxalate are also present.

\section{Powder of the fruit (Fig. 20)}

The powdered fruit is greenish brown in colour, odourless, having a slightly bitter astringent taste. It is characterized by the following:

1- Fragments of the epicarp showing polygonal cells, with straight anticlinal walls and covered with thick cuticle.
2- Fragments of the cork cells of the stalk of the fruit showing polygonal cells with thin straight anticlinal walls.

3- Fragments of clusters and prisms of calcium oxalate either free or enclosed in the cells.

4- Fragments showing spiral and reticulate lignified xylem vessels.

5- Fragments of pitted wood parenchyma, some of them are lignified and others are not.

6- Fragments of pitted, lignified tracheides.

7- Few starch granules which are mainly simple with cleft centric hilum.

8- Fragments of pericyclic fibres which are lignified with slightly dentate walls and having relatively wide lumina.

9- Fragments of the phloem fibres with slightly narrow lumina.

10- Fragments of wood fibres.

11- Fragments of sclerides of the pericarp. 


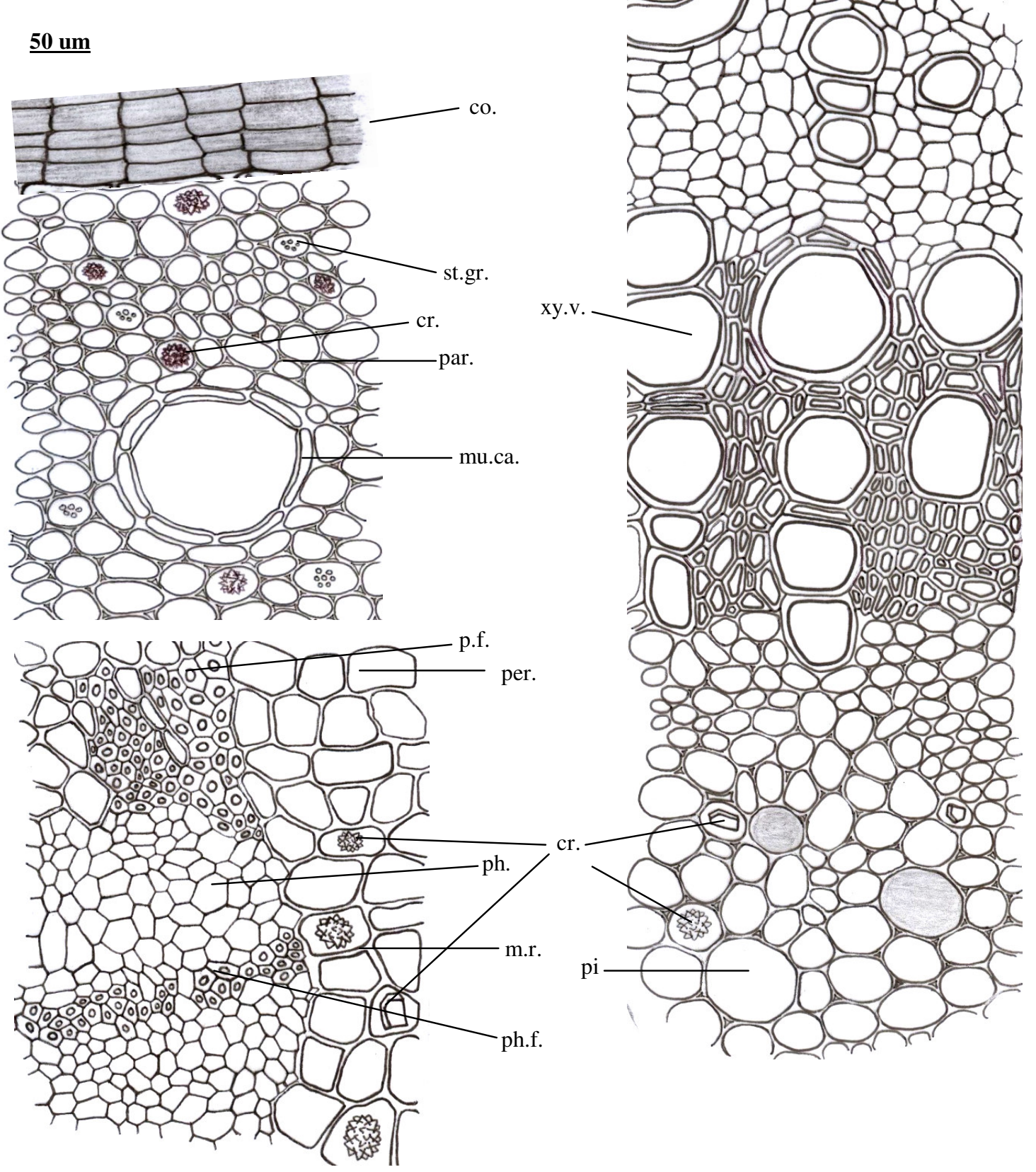

Fig. 19: The detailed T.S. of the stalk of the fruit.

co., cork; cr., crystal; m.r., medullary rays; mu.ca., mucilage cavity; p.f., pericyclic fibre; par., parenchyma; per., pericycle; ph., phloem; ph.f., phloem fibre; pi., pith; st.gr., starch granules; xy.v., xylem vessels; 


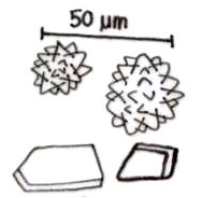

cr.

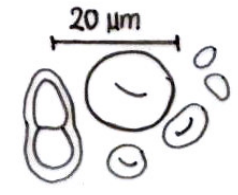

st.gr.

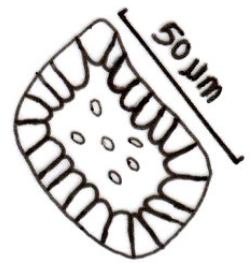

scl.

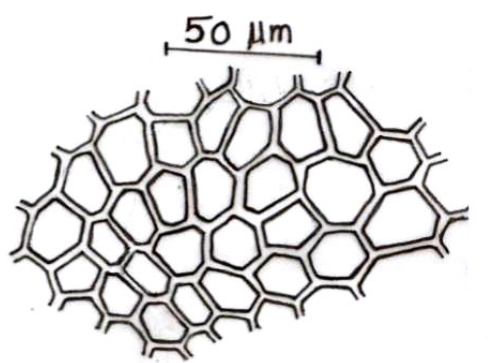

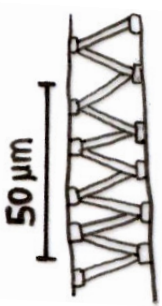

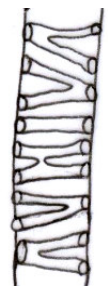

xy.v.

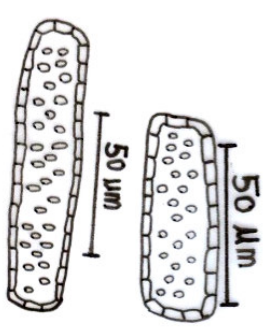

w.par.

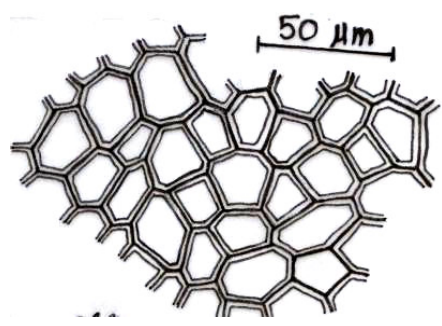

co.

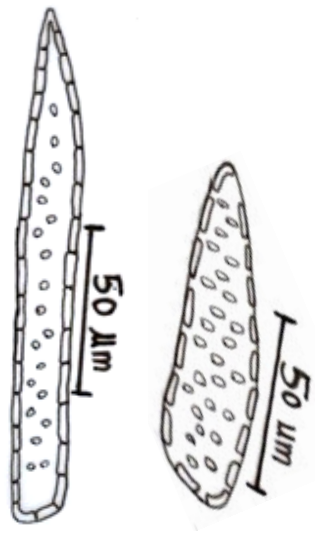

tr. ep.

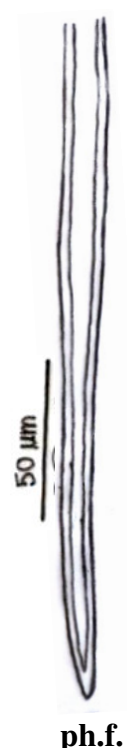

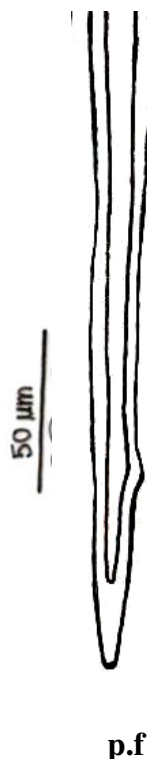

p.f

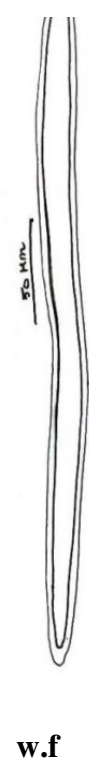

W.f

Fig. 20: Powder of the pericarp and the stalk of the fruit:

cr., crystals; co., cork cells; ep., epicarp; p.f., pericyclic fibre; ph., phloem fibre; scl., sclerides; st.gr., starch granules; tr., tracheides; w.par., wood parenchyma; xyl.v., xylem vessels. 
Table 1: Microscopical measurements of the leaf, stem, stem bark and fruit of Chorisia speciosa A. St. Hil. (In microns):

\begin{tabular}{|c|c|c|c|c|}
\hline Item & Length & Width & Diameter & Height \\
\hline \multicolumn{5}{|l|}{ Lamina } \\
\hline Upper epidermis & $19-\underline{30-64}$ & $14-\underline{35-44}$ & & $10-17-22$ \\
\hline Lower epidermis & $12-\underline{30-52}$ & $15-\underline{22}-40$ & & 6-10-18 \\
\hline Neural epidermis & $32-\underline{70-92}$ & $8-15-22$ & & $10-15-21$ \\
\hline Non-glandular hair & 610-670-750 & $9-\underline{13}-20$ & & \\
\hline Glandular hair & $63-\underline{80-102}$ & & $12-21-32$ & \\
\hline Stomata & $16-\underline{25-30}$ & & $7-\underline{11-16}$ & \\
\hline Palisade & $19-\underline{33}-43$ & $4-7-10$ & & \\
\hline Parenchyma & & & $18-\underline{30-47}$ & \\
\hline Collenchyma & & & 4.5- $\underline{-9}-17$ & \\
\hline Pericyclic fibers & 270-324-390 & & 5-15-27 & \\
\hline Wood fibres & $102-400-750$ & & 4-11-16 & \\
\hline Xylem vessels & & & $16-20-32$ & \\
\hline Wood parenchyma & $50-85-120$ & $14-\underline{36}-43$ & & \\
\hline Tracheides & $125-\underline{-210-285}$ & $10-\underline{30}-42$ & & \\
\hline Clusters & & & $11-\underline{25-40}$ & \\
\hline Starch & & & 3-11-19 & \\
\hline Cavity & & & $32-\underline{54-70}$ & \\
\hline Medullary ray & $25-\underline{33}-47$ & $16-\underline{20-26}$ & & \\
\hline \multicolumn{5}{|l|}{ Petiole } \\
\hline Epidermis & $19-38-53$ & $11-18-22$ & & $17-19-21$ \\
\hline Parenchyma & & & $16.5-31.75-34$ & \\
\hline Collenchyma & & & $9-17-32$ & \\
\hline Xylem vessels & & & $18-\underline{26}-35$ & \\
\hline Clusters & & & $19-\underline{30-40}$ & \\
\hline Tracheides & $120-290-375$ & $15-\underline{28}-40$ & & \\
\hline Pericyclic fibers & $270-\underline{324}-390$ & & 5-15-27 & \\
\hline Wood fibres & $102-\underline{250}-430$ & & 4-11-16 & \\
\hline \multicolumn{5}{|l|}{ Young stem } \\
\hline Epidermal cells & $19-\underline{25-36}$ & 10.4-17.7-20 & & 14-16-18 \\
\hline Parenchyma & & & 6-28-50 & \\
\hline Mucilage cavity & & & $27-92-185$ & \\
\hline Pericyclic fibers & $350-639-928$ & & $6.5-20-30$ & \\
\hline Xylem vessels & & & $10-\underline{30-87}$ & \\
\hline Wood parenchyma & $45-\underline{50-65}$ & $10-\underline{28}-47$ & & \\
\hline Wood fiber & $250-290-330$ & & $6-\underline{15-29}$ & \\
\hline Medullary rays & $20-27.5-35$ & $12.5-22-31.5$ & & \\
\hline
\end{tabular}


Table 1: Continued.

\begin{tabular}{|c|c|c|c|c|}
\hline Item & Length & Width & Diameter & Height \\
\hline Tracheids & $150-\underline{-261-391}$ & $19-\underline{30}-41$ & & \\
\hline Clusters & & & $10-\underline{20}-33$ & \\
\hline Prisms & $4-14-22$ & $8-\underline{15-20}$ & & \\
\hline Starch & & & $2-\underline{8-16}$ & \\
\hline \multicolumn{5}{|l|}{ Stem bark } \\
\hline Cork cells & $16-\underline{\underline{25}-34}$ & 6-13-20 & & $8.75-\underline{13.7-18.75}$ \\
\hline Chlorenchyma & & & $17-\underline{40-55}$ & \\
\hline Parenchyma & & & 26- $\underline{50-77}$ & \\
\hline Pericyclic fibre & $1050-1170-1243$ & & $8-17-26$ & \\
\hline Phloem fibers & $\underline{1510}-1663-1400$ & & $8-\underline{15}-29$ & \\
\hline Sclerides & $20-\underline{33}-41$ & $20-\underline{35-53}$ & & \\
\hline Medullary rays & $15-\underline{25}-44$ & $10-\underline{30}-42$ & & \\
\hline Clusters & & & $20-\underline{35}-47$ & \\
\hline Prisms & $21-\underline{27-32}$ & $10-\underline{18}-27$ & & \\
\hline \multicolumn{5}{|l|}{ Fruit } \\
\hline Epicarp & $10-\underline{18}-24$ & 4-13-20 & $17.5-\underline{25-37}$ & \\
\hline Parenchyma & & & & $28-44-59$ \\
\hline Sclerides & $17-\underline{35-55}$ & $15-\underline{-30}-42$ & & \\
\hline Cavity & & & & 119-130-142 \\
\hline Cluster & & & & $31-\underline{38-43}$ \\
\hline \multicolumn{5}{|l|}{ Stalk of fruit } \\
\hline Cork & $8-20-33$ & $6-18-31$ & $8-12-16$ & \\
\hline Parenchyma & & & & $10-27-44$ \\
\hline Cavity & & & & $54-95-131$ \\
\hline Cluster & & & & $13-22-33$ \\
\hline Prism & $8.5-10-18.5$ & $8.5-10-13$ & & \\
\hline Xylem vessels & & & & $21-45-76$ \\
\hline Wood parenchyma & $43-57-96$ & & & $17-24-29$ \\
\hline Wood fibers & $650-900-1200$ & & & 4-14-20 \\
\hline Pericyclic fibers & $1200-1370-1500$ & & & $6.5-13-18$ \\
\hline Phloem fibers & $400-580-670$ & & & $4.5-8-11$ \\
\hline Tracheids & $86-123-170$ & $13-17-24$ & & \\
\hline Tracheidal vessels & $240-256.2-272.5$ & $10-12.5-15$ & & \\
\hline
\end{tabular}




\section{REFERENCES}

1- A. B. Joly, "Botany: An Introduction to Plant Taxonomy", $10^{\text {th }}$ Ed., Sao Paulo: National Publishing Company, 1991, p. 462.

2- L. Benson, "Plant Classification", New Delhi, Bombay: Oxford and IBH publishing Co., 1970, pp. 793-797.

3- A. A. Hassan, "Phytochemical and Biological Investigation of Certain Plants Containing Pigments", A Thesis for the Doctor Degree submitted to Faculty of Pharmacy, Mansoura University, Egypt (2009).

4- A. Huxley, "Dictionary of Gardening: The New Royal Horticultural Society", The Macmillan Press Limited, London, the Stockton Press, New York (1992).

5- L. H Bailey, "Hortus Third: A Concise Dictionary of Plants Cultivated in the United States and Canada", Staff of the L.H. Bailey Hortorium, Cornell University (1976).

6- E. J. Adjanohoun, "Contribution aux Etudes Ethnobotaniques et Floristiques en Republique Populaire du Congo, ACCT", Paris, 1988, p. 605.

7- A. M. Ashmawy, S. S. Azab and O. A. Eldahshan, "Effects of Chorisia crispiflora ethyl acetate extract on P21 and NF-jB in breast cancer cells", $\boldsymbol{J} . \mathbf{A m}$. Sci., 8, 965-972 (2012).
8- S. S. Hafez, A. E. Abdel-Ghani and A. M. El-Shazly, "Pharmacognostical and antibacterial studies of Chorisia speciosa St. Hil. flower (Bombacaeae)", Mans. J. Pharm. Sci., 19, 40-43 (2003).

9- T. S. El-Alfy, S. A. El-Sawi, A. Sleem and D. M. Moawad, "Investigation of flavonoidal content and biological activities of Chorisia insignis H.B.K. leaves", Aust. J. Basic Appl. Sci., 4, 13341348 (2012).

10- J. Refaat, M. N. Samy, S. Y. Desoukey, M. A. Ramadan, M. Sugimoto, K. Matsunami, and M. S. Kamel, "Chemical constituents from Chorisia chodatii flowers and their biological activities", Med. Chem. Re., 24 (7), 2939-2949 (2015b).

11- P. Ravenna, "On the identity, validity and actual placement in Ceiba of several Chorisia species (Bombacaceae) and description of two new South American species", Oniro, 3 (15), $42-51$ (1988).

12- M. K. Stebbins, "Flowering Trees of Florida", $1^{\text {st }}$ Ed., Pineapple Press, Inc., Library of Congress Cataloging-inPublication Data, 1956, pp. 54-57.

13- R. Metcalfe and Chalk, "Anatomy of Dicotyledons", The Clarendon Press, Oxford, I, 1950, pp. 236-242.

14- T. EI Alfy, S. El Sawi, S. Abd El Tawab and D.Moawad, "Pharmacognostical study of Chorisia insignis HBK grown in Egypt", Bulletin of Faculty of Pharmacy, Cairo University, 50, 17-39 (2012). 


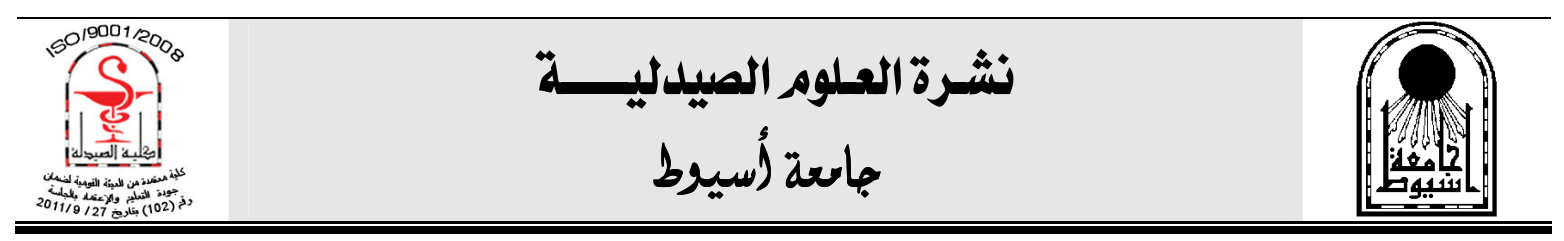

دراسة عينية ومجهرية لأوراق وساق وقتف الساق وثمار نبات كوريزيا اسبسيوزا

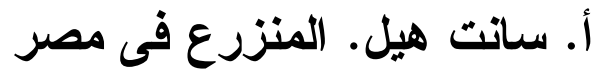

محمود أحمد رمضان - فاتن مصطفى درويش - محمود حافظ عساف - ايرينى محسن نصر فير لمرل قسم العقاقير ، كلية الصيدلة ، جامعة أسيوط ، أسيوط ، مصر لركر

نبات الكوريزيا اسبسيوز ا التابع للعائلة البومباكيسية ويستخدم فــى الطــبـ الــشعبى كمـسكن

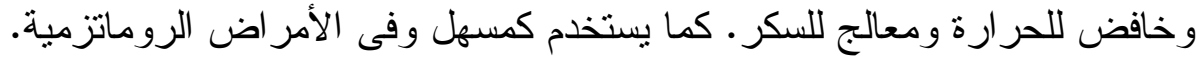

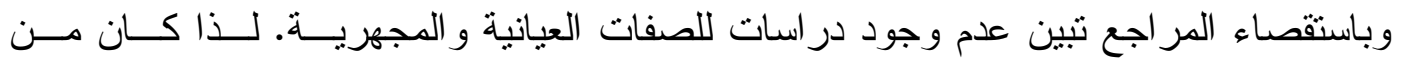

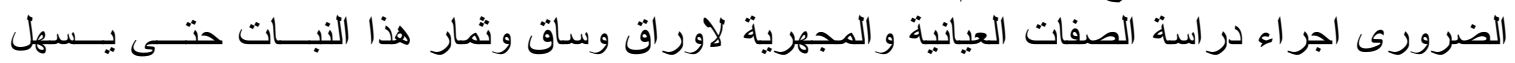
التعرف عليه فى حالته الصحيحة أو على هيئة مسحوق. لالته 